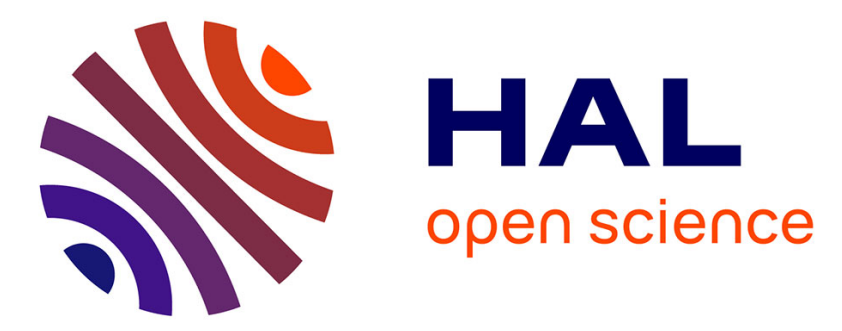

\title{
The São Francisco cratonic root beneath the Neoproterozoic Brasilia belt (Brazil): Petrophysical data from kimberlite xenoliths
}

Priscila Rezende Fernandes, Andrea Tommasi, Alain Vauchez, Sérgio Pacheco

Neves, Felix Nannini

\section{To cite this version:}

Priscila Rezende Fernandes, Andrea Tommasi, Alain Vauchez, Sérgio Pacheco Neves, Felix Nannini. The São Francisco cratonic root beneath the Neoproterozoic Brasilia belt (Brazil): Petrophysical data from kimberlite xenoliths. Tectonophysics, 2021, 816, pp.229011. 10.1016/j.tecto.2021.229011. hal-03320605

\section{HAL Id: hal-03320605 \\ https://hal.science/hal-03320605}

Submitted on 16 Aug 2021

HAL is a multi-disciplinary open access archive for the deposit and dissemination of scientific research documents, whether they are published or not. The documents may come from teaching and research institutions in France or abroad, or from public or private research centers.
L'archive ouverte pluridisciplinaire $\mathbf{H A L}$, est destinée au dépôt et à la diffusion de documents scientifiques de niveau recherche, publiés ou non, émanant des établissements d'enseignement et de recherche français ou étrangers, des laboratoires publics ou privés. 
Please cite as: Fernandes, P.R., Tommasi, A., Vauchez, A. The São Francisco craton root beneath the Neoproterozoic Brasilia belt (Brazil): Petrophysical data from kimberlite xenoliths. Tectonophysics, 816: 229011, doi: 10.1016/ j.tecto.2021.229011

\title{
The São Francisco cratonic root beneath the Neoproterozoic Brasilia belt (Brazil): Petrophysical data from kimberlite xenoliths
}

\author{
Priscila Rezende Fernandes ${ }^{\mathrm{a}, *}$, Andréa Tommasi $^{\mathrm{b}}$, Alain Vauchez ${ }^{\mathrm{b}}$, Sérgio Pacheco Neves ${ }^{\mathrm{c}}$, \\ Felix Nannini ${ }^{\mathrm{d}}$ \\ ${ }^{a}$ Serviço Geológico do Brasil (CPRM), Brazil \\ ${ }^{\mathrm{b}}$ Géosciences Montpellier, CNRS \& Université de Montpellier, France \\ ${ }^{\mathrm{c}}$ Instituto de Geociencias, Universidade Federal de Pernambuco (UFPE), Brazil \\ ${ }^{\mathrm{d}}$ Universidade Federal de Uberlândia (UFU), Brazil
}

\section{A R T I C L E I N F O}

\section{Keywords:}

Craton

Mantle

Olivine

Deformation

Annealing

Metasomatism

Melt-rock reaction

Seismic anisotropy

Seismic velocities

\begin{abstract}
A B S T R A C T
Petrostructural analysis of 31 mantle xenoliths from three kimberlitic pipes intruding the Neoproterozoic Brasilia belt close to the southwestern margin of the São Francisco craton (SFC) reveals microstructures and compositions similar to those observed in cratonic roots worldwide. (1) The spinel-peridotites sampling the upper section of the lithospheric mantle have dominantly refractory modal and mineral compositions, whereas garnet-peridotites sampling the deep lithospheric mantle have more fertile compositions, consistent with those observed in cratonic roots worldwide. (2) The spinel-peridotites present a variation in microstructure from coarse-granular to coarseporphyroclastic, but similar olivine crystallographic preferred orientations (CPO). (3) The garnet-peridotites have fine-porphyroclastic microstructures. (4) Many coarse-porphyroclastic spinel-peridotites display Feenrichment in olivine and pyroxenes, often associated with Ti-enrichment in pyroxenes or spinel and occurrence of modal phlogopite. (5) Equilibrium temperatures and pressures of garnet-peridotites are consistent with a cratonic geotherm, but equilibrium conditions of spinel-peridotites require a warmer geotherm. We interpret these observations as indicating that the xenoliths sample the SFC mantle root, which extends beneath the Brasilia belt, but was modified by reactive transport of the magmas forming the Alto Parnaiba Igneous Province (APIP) between 120 and 90 Ma. The APIP magmatism resulted in heterogeneous modal metasomatism, Fe enrichment, development of coarse-porphyroclastic microstructures in spinel peridotites and fineporphyroclastic microstructures in garnet-peridotites, and moderate heating of the cratonic mantle root. These changes may produce a decrease in seismic velocities explaining the local weak negative anomaly observed in the lithospheric mantle beneath the APIP, which contrasts with the positive velocity anomalies characterizing the SFC mantle root in P-wave tomography models. However, reactive magma transport did not erase the olivine CPO. Comparison of the average seismic properties of the xenoliths with seismological data implies dominantly subhorizontal fossil flow directions and a non-negligible contribution of the cratonic root to teleseismic S-waves splitting.
\end{abstract}

\section{Introduction}

Cratons, with their thick, buoyant, chemically depleted, low heat flow, and high strength lithospheric mantle (Boyd and Mertzman, 1987; Durrheim and Mooney, 1991; Griffin et al., 1998; King, 2005), play an essential role in the tectonic evolution of continental plates. They constitute the strong nuclei around which continents have grown, exerting a major control on the deformation and magmatism distribution at the plate scale (e.g., Tommasi and Vauchez, 2015 and references therein). However, the processes leading to the formation and allowing for the longevity of cratonic roots over billions of years are still debated (cf. reviews on craton formation processes in Griffin et al., 2003 and Arndt et al., 2009 and numerical models testing the stability of cratonic roots in Doin et al., 1997 and Lenardic et al., 2003).

The São Francisco craton (SFC) is a key element in the construction of western Gondwana. It played a major role on many of the late 
Neoproterozoic to early Paleozoic collisions leading to the amalgamation of this supercontinent (Valeriano et al., 2008). These collisions are presently recorded by the orogenic belts that surround the SFC: the Ribeira-Araçuaí system in the SE, the Brasilia-Tocantins system in the WSW and W, and the Borborema Province in the NNE (Fig. 1). However, its actual limits are still debated. Geophysical observations, such as negative Bouguer anomalies and faster than average seismic velocities, consistently point to a larger extent of the craton at depth than its present outcropping area, especially beneath the Brasilia and Ribeira-Araçuaí Neoproterozoic collisional belts (Assumpção et al., 2004; Pereira and Fuck, 2005; Rocha et al., 2011; Assumpção et al., 2017; Rocha et al., 2019). However, beneath the eastern Brasilia belt, the seismic tomography models show a smaller low velocity anomaly that hints at modification of the lithospheric mantle beneath the Brasilia belt by the Cretaceous magmatism forming the Alto Parnaíba Igneous Province (APIP), one of the world's most voluminous mafic potassic igneous provinces (Gibson et al., 1995).

This study aims to test the existence of a cratonic mantle root beneath the eastern Brasilia belt and to determine the possible effects of the APIP magmatism on the seismic properties of the lithospheric mantle in this region. These questions are fundamental for constraining: (1) the paleo-geometry of the SFC, with implications of the geodynamical evolution of the South America plate, and (2) the ability of a major magmatic event to change the lithospheric mantle, with implications for cratons longevity. We investigate these questions through a petrophysical study of 31 mantle xenoliths carried to the surface by three APIP

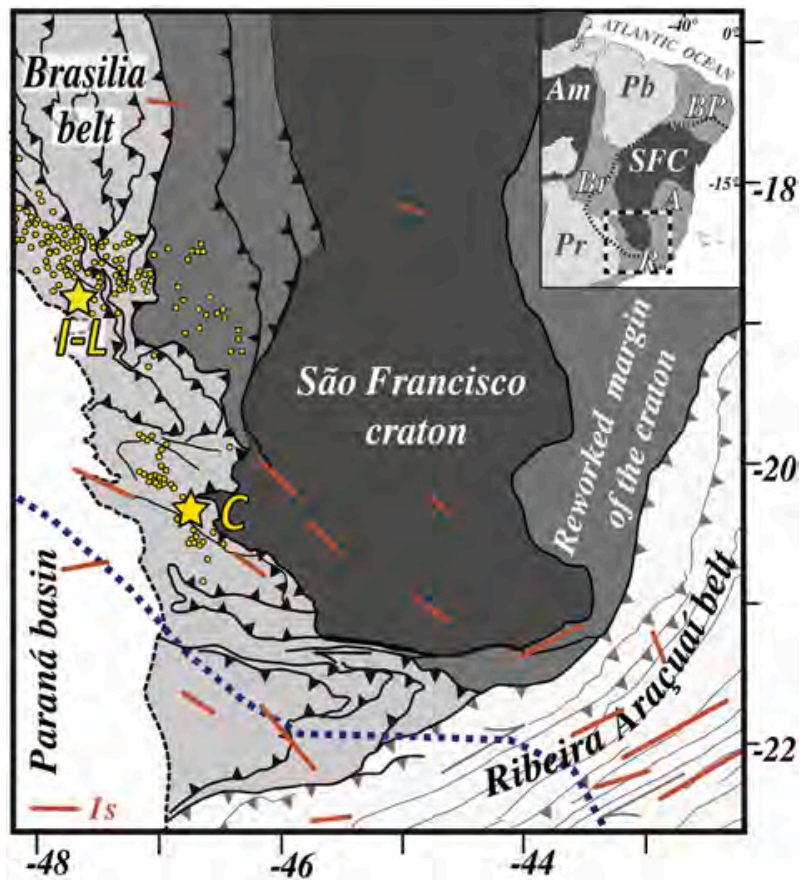

Fig. 1. Schematic map of eastern Brazil showing the São Francisco craton and surrounding Neoproterozoic orogenic belts, which strongly remobilized the western and eastern margins of the craton. The studied samples were extracted from the mantle by Cretaceous kimberlites intruding the Brasilia belt (yellow stars): Canastra-1 (C) and Indaiá-1 and Limeira-1 (I-L) kimberlites. Yellow dots mark other Alto Parnaiba Igneous Province volcanics. The inset (modified from Assumpção et al., 2013) locates the map in northeastern South America. Cratons are depicted in dark gray (Am: Amazonian craton, SFC: São Francisco craton), Neoproterozoic belts in medium gray (Br: Brasilia; R: Ribeira; A: Araçuaí; BP: Borborema Province), and Paleozoic basins in light gray (Pr: Paraná; $\mathrm{Pb}$ : Parnaiba). The dashed blue contour in both maps marks the limit of the São Francisco craton at depth inferred from seismic and gravity data (Rocha et al., 2019). Red bars are teleseismic shear wave splitting data from Melo and Assumpção (2018). (For interpretation of the references to colour in this figure legend, the reader is referred to the web version of this article.) kimberlites of different ages (120, 90, and $81 \mathrm{Ma})$, which intruded the Neoproterozoic Brasilia belt close to the southwestern outcropping boundary of the SFC. We characterized the xenoliths microstructures and their relations with modal and major-element mineral compositions, measured the crystal-preferred orientations of olivine and pyroxenes, and estimated equilibrium temperature and pressure conditions. Based on these data, we calculated the seismic properties of the lithospheric mantle, which we compare to seismological data in SE Brazil.

\section{Geological setting}

The studied xenoliths were extracted from the mantle during the Cretaceous by kimberlites from the APIP, a NW-SE elongated volcanic field emplaced in the Brasilia belt, between the SFC and Paraná basin (Fig. 1). The APIP $\left(>15,000 \mathrm{~km}^{3}\right)$ involves a rather diverse suite of ultrapotassic-potassic, ultramafic-mafic, silica-undersaturated lavas and hypabyssal intrusions (kimberlites, olivine lamproites, and kamafugites; Gibson et al., 1995). The role of a mantle plume in triggering the APIP magmatism is still debated (Gibson et al., 1995; Carlson et al., 1996, 2007; Guarino et al., 2013). However, geochemical data converge on that the APIP magmatism results from low degrees $(<2 \%)$ of melting of a heterogeneous subcontinental mantle, which was depleted by melt removal during the Archean or late Proterozoic and re-enriched by metasomatism, probably in the Neoproterozoic (Gibson et al., 1995; Carlson et al., 1996, 2007; Guarino et al., 2013). Most APIP kimberlites, including the Limeira-1 and Indaiá-1 bodies from which the presently studied spinel-peridotites are derived, have ages ranging between 91 and 80 Ma (Read et al., 2004; Guarino et al., 2013). However, some diamond-bearing kimberlites, like the Canastra-1 body where the presently studied garnet-peridotites have been collected, are as old as 120 Ma (Pereira and Fuck, 2005). The youngest expressions of this magmatic event are extrusives kamafugites (81-61 Ma; Read et al., 2004; Guarino et al., 2013).

The kimberlites that carried the studied peridotites are intrusive in the nappes of the external (pipe Canastra-1) or internal (pipes Limeira-1 and Indaiá-1) domains of the Brasilia belt (Fig. 1). These structures result from the collision of the Paranapanema and Goiás microcontinents and the Goiás magmatic arc with the SFC at 640-610 Ma (Valeriano et al., 2008). The external domain is extremely narrow in the study area (Fig. 1), where it is composed of an imbricated stack of eastverging tectonic nappes that thrusted Neoproterozoic passive margin formations (metasedimentary and metavolcanic rocks, with predominance of siliciclastic units) above the craton. The deformation of the outcropping formations occurred mainly under greenschist conditions. It is characterized by a gently west-dipping foliation of variable intensity, locally reworked by upright folding. Displacements are dominantly towards the craton (Ulhein et al., 2013; Valeriano et al., 2008). Basement rocks with Archean to Paleoproterozoic ages outcrop in anticlinal folds between the nappes and locally within the thrust slices. WNW-oriented sinistral strike-slip faults acted as transfer zones between the thrust systems (Ulhein et al., 2013; Valeriano et al., 2008). The internal domain of the Brasilia belt comprises a series of east-verging nappes that override the thrust-and-fold belt of the external zone. These nappes are composed of metasedimentary sequences deposed on a distal shelf or slope environment intercalated with metavolcanics. They display an inverted metamorphic gradient from amphibolite or even granulite to greenschist facies (Valeriano et al., 2008). West of the study region, the continuation of the Brasilia belt is covered by the Paraná Basin (Fig. 1). To the northwest, the Brasilia belt transitions to the Goiás massif, which is interpreted as a microcontinent formed between 3 and $0.8 \mathrm{Ga}$ (Valeriano et al., 2008), and to the Neoproterozoic Goiás magmatic arc, formed between 890 and $640 \mathrm{Ma}$ (Pimentel et al., 2004).

In the vicinity of the study area, the Archean to Paleoproterozoic basement of the SFC is mainly covered by Neoproterozoic sediments of the São Francisco Supergroup (Fig. 1), but 3.2-2.7 Ga old greenstone 
belt and TTG associations crop out farther south and east. The São Francisco Supergroup comprises coastal carbonated sediments (Salitre Formation), platform carbonate and siliciclastics rocks (Bambuí Group), and terrestrial sediments interspersed with carbonates (Três Marias Group; Bizzi et al., 2003). It also contains diamictites correlated to the Sturtian (ca. 715-660 Ma) or Marinoan (635 Ma) worldwide glaciations (Figueiredo et al., 2009; Babinski et al., 2012). Some studies propose that the Bambuí sedimentation may be as young as $560 \mathrm{Ma}$, representing a foreland basin associated with the Brasilia orogeny (Paula-Santos et al., 2015). However, the Neoproterozoic deformation that formed the Brasília belt also generated folds and shallow sub-horizontal thrusts in the sediments the São Francisco Supergroup (Fig. 1; Dardenne, 2000).

In the present study, we analyze mantle xenoliths from three APIP kimberlitic pipes. The Canastra-1 kimberlitic body (C in Fig. 1) is intrusive ingreenschist facies metasedimentary nappes (Canastra group) of the externaldomain of the Brasilia belt. This pipeis located at $\sim 25 \mathrm{~km}$ west of the outcropping limit of the SFC, which is marked by a low-angle thrust that carried the Brasilia belt units onto the sediments of the São Francisco Supergroup (Fig. 1). The Canastra-1 kimberlite pipe was the first economically viable mineralized kimberlitic body discovered in Brazil (Cabral Neto et al., 2017). K-Ar dating on phlogopite produced ages of $120 \pm 10 \mathrm{Ma}$ for this kimberlite (Pereira and Fuck, 2005). The kimberlitic bodies Indaiá-1 and Limeira-1 (I-L on Fig. 1), also known as Perdizes-03-A and Perdizes-04-A, are intrusive in the 790 Ma old Monte Carmelo granitic complex (Nannini, 2016). This granitic complex was strongly reworked at ca. 630 Ma during the Brasilia orogeny, when it was extensively deformed in an east-verging nappe together with amphibolite and amphibole-chlorite schists of the Araxá group in the internal domain of the Brasilia belt (Seer and de Moraes, 2013). The Indaiá-1 and Limeira-1 kimberlites are located $\sim 60-70 \mathrm{~km}$ west of the outcropping limit of the SFC. In situ $\mathrm{U}-\mathrm{Pb}$ perovskite data produced ages of $80 \pm 5 \mathrm{Ma}$ for the Indaiá-1 and of $91 \pm 6$ Ma for the Limeira-1 kimberlite (Guarino et al., 2013).

Previous studies on peridotite xenoliths and xenocrysts from the APIP magmatic bodies focused on their mineralogy and geochemistry, aiming to unravel their ages, chemical evolution, and the thermal gradient prevailing in the lithospheric mantle at the extraction times (Carvalho and Leonardos, 1997; Carlson et al., 2007; Costa, 2008; Nannini, 2016). Garnet and spinel-peridotites from the Coromandel kimberlite field, which includes the Limeira- 1 and Indaiá-1 bodies and the 95 Ma-old diamond-bearing Três Ranchos kimberlite, are depleted in $\mathrm{Ca}, \mathrm{Al}$, and $\mathrm{Re}$ and display Re-depletion model ages between 1.9 and 3.7 $\mathrm{Ga}$, supporting that the APIP province is underlain by early-Proterozoic to late-Archean refractory lithospheric mantle of the SFC (Carlson et al., 2007). However, petrological and geochemical data for the spinelperidotites from the Limeira-1 and Indaiá-1 kimberlites indicate chemical modification of this refractory mantle lithosphere by reactive percolation of fluids or melts, which produced both cryptic and modal metasomatism, including crystallization of phlogopite, secondary clinopyroxene, ilmenite, and amphibole (Nannini, 2016). Thermobarometric data for most garnet-peridotite xenoliths from the Canastra- 1 and Três Ranchos-4 kimberlites fit to a typical cold cratonic geotherm, consistent with a surface heat flow of $40 \mathrm{~mW} / \mathrm{m}^{2}$, which places the deep $(>120 \mathrm{~km}$ ) lithospheric mantle in the diamond stability field (Carvalho and Leonardos, 1997; Costa, 2008). However, comparison of thermobarometric estimates based on the composition of clinopyroxene xenocrysts in early Cretaceous kimberlites and late Cretaceous kamafugites erupted onto the SFC sedimentary cover, $\sim 50-100 \mathrm{~km}$ to the southwest of the Limeira- 1 and Indaiá-1 bodies, implies heating of the lithospheric mantle by $\sim 250{ }^{\circ} \mathrm{C}$ between 89 and $85 \mathrm{Ma}$, placing most of the lithospheric mantle beneath the APIP into the graphite stability field by the late Cretaceous (Read et al., 2004).

\section{Methods}

\subsection{Sampling}

We studied 31 samples of mantle xenoliths brought to the surface by the APIP kimberlitic magmatism (Table 1). 21 spinel peridotites from the pipes Indaiá-1 and Limeira-1 (labelled In1-XX and Lm1-XX, respectively - Table 1) from the Monte Carmelo district in the Coromandel region, previously studied for their chemistry by Nannini (2016), and 10 garnet-bearing peridotites and pyroxenites from the pipe Canastra-1 (labelled C-XX - Table 1), previously studied for their equilibrium pressure and temperature conditions by Costa (2008).

\subsection{Crystallographic preferred orientations}

Crystallographic preferred orientations (CPO) of olivine, pyroxenes, garnet, spinel, and phlogopite have been measured through indexation of electron backscattered diffraction (EBSD) patterns produced by interaction of a vertical incident electron beam and a carefully polished thin section tilted at $70^{\circ}$ to the horizontal. Measurements were performed in the Geosciences Montpellier SEM-EBSD facility using a JEOL JSM 5600 scanning electron microscope equipped with a Nordlys II EBSD Detector and AZtecHKL software from Oxford Instruments. We used an acceleration voltage of $17 \mathrm{kV}$ and a working distance of $24 \mathrm{~mm}$. Crystal orientation maps covering nearly the entire thin section were obtained for all samples using steps between $15 \mu \mathrm{m}$ and $50 \mu \mathrm{m}$, depending on grain size. Indexing rates varied from $60 \%$ to $90 \%$, depending on the degree of fracturing and reaction with the host kimberlitic magmas in the thin section. During post-acquisition data treatment, we eliminated inaccurate indexing points (MAD $>1.3^{\circ}$ and wild spikes), corrected for rare misindexing due to olivine pseudo-symmetry, and filled up non-indexed pixels having at least six coherent neighboring measurements with the average of the neighbors' orientations. This procedure was controlled by comparing EBSD maps to observations in optical microscopy.

We performed EBSD data analysis using the MTEX toolbox in Matlab (http://mtex-toolbox.github.io/; Hielscher and Schaeben, 2008; Bachmann et al., 2010; Bachmann et al., 2011). This analysis included the calculation of the orientation distribution functions (ODF), the analysis of the misorientation within grains and at grain boundaries, the quantification of grain size and shapes, and plotting of pole figs. A "de la Vallée Poussin" kernel function with a half-width of $10^{\circ}$ was used to calculate the ODF. To prevent overrepresentation of large grains, CPOs are plotted in lower hemisphere stereographic projections using the mean orientation of each grain. Because of the small size of the xenoliths, the thin sections were cut in random orientations relative to the foliation and lineation. To allow easy comparison among different samples, all CPO data were rotated into a common orientation, with the maximum concentration of olivine [100]-axis in the E-W direction and the maximum concentration of the [010]-axis in the N-S direction of the pole figure.

The strength of the olivine $\mathrm{CPO}$ was quantified using the dimensionless $\mathrm{J}$-index $(1=$ random $\mathrm{CPO}$ and $\infty=$ perfect alignment; Bunge, 1982). In naturally deformed peridotites, the J-index, when calculated using the same parameters as in this study, ranges between 1 and 18 (strong CPO), with an average at $\sim 4.8$ (Tommasi and Vauchez, 2015). Jindex was calculated using both one-orientation datum per pixel and the mean orientation of each grain. The first option, which is presented in the figures, allows relating the CPO strength to variations in grain size. Large crystals contribute more to the J-index and to the anisotropy of physical properties. The olivine CPO symmetry is characterized by the dimensionless BA-index (Mainprice et al., 2014). This index allows classifying the olivine CPO symmetry into 3 types: (1) fiber-[010], characterized by a point concentration of [010] and distribution of [100] within a girdle orthogonal to [010] (BA-index $<0.35$ ), (2) orthorhombic, characterized by point concentrations of both [100] and [010] 
Table 1

Provenance, lithology, modal compositions and equilibrium conditions for all studied samples.

\begin{tabular}{|c|c|c|c|c|c|c|c|c|c|c|c|c|}
\hline \multirow[t]{2}{*}{ Sample } & \multirow[t]{2}{*}{ Pipe } & \multirow[t]{2}{*}{ Rock Type } & \multirow[t]{2}{*}{ Microstructure } & \multicolumn{7}{|c|}{ Modal composition (\%) } & \multirow[t]{2}{*}{$T\left({ }^{\circ} \mathrm{C}\right)$ Ca-in-Opx } & \multirow{2}{*}{$\begin{array}{l}P(G P a) \\
\text { Opx-Gt }\end{array}$} \\
\hline & & & & $\mathrm{Ol}$ & Opx & $\mathrm{Cpx}$ & $\mathrm{Sp}$ & Gt & $\mathrm{Phl}$ & Par & & \\
\hline C-100 & Canastra 1 & Garnet lherzolite & Fine-porphyroclastic & 69 & 13 & 11 & 0 & 6 & 0 & 0 & 1232 & 5.2 \\
\hline C-104 & Canastra 1 & Garnet lherzolite & Fine-porphyroclastic & 64 & 16 & 18 & 0 & 2 & 0 & 0 & 1236 & 5.4 \\
\hline C-106a & Canastra 1 & Garnet lherzolite & Fine-porphyroclastic & 60 & 30 & 7 & 0 & 4 & 0 & 0 & 1238 & 5.3 \\
\hline C-106b & Canastra 1 & Garnet harzburgite & Fine-porphyroclastic & 40 & 52 & 5 & 0 & 3 & 0 & 0 & 1238 & - \\
\hline C-94 & Canastra 1 & Clinopyroxenite\# & Coarse-granular & 0 & 10 & 60 & 0 & 30 & 0 & $<1$ & - & - \\
\hline C-147 & Canastra 1 & Clinopyroxenite\# & Coarse-granular & 0 & 3 & 46 & 0 & 50 & 0 & 1 & - & - \\
\hline C-95 & Canastra 1 & Websterite & Coarse-granular & 0 & 28 & 37 & 0 & 16 & 0 & 19 & 973 & - \\
\hline C-203 & Canastra 1 & Websterite & Coarse-granular & 0 & 24 & 45 & 0 & 29 & 0 & 2 & 790 & - \\
\hline C-127 & Canastra 1 & Websterite & Coarse-porphyroclastic & 0 & 51 & 21 & 0 & 0 & 0 & 29 & 887 & - \\
\hline C-150 & Canastra 1 & Websterite & Coarse-porphyroclastic & 0 & 48 & 40 & 0 & 0 & 0 & 12 & 990 & - \\
\hline In1-3 & Indaiá 1 & Spinel lherzolite & Coarse-granular & 73 & 21 & 3 & 1 & 0 & 0 & 0 & 811 & - \\
\hline In1-4 & Indaiá 1 & Spinel lherzolite & Coarse-granular & 71 & 16 & 12 & 1 & 0 & 0 & 0 & 711 & - \\
\hline In1-5 & Indaiá 1 & Dunite & Coarse-granular & 93 & 5 & 1 & 0 & 0 & 1 & 0 & 681 & - \\
\hline In1-6 & Indaiá 1 & Spinel lherzolite & Coarse-granular & 49 & 36 & 11 & 2 & 0 & $<1$ & 0 & - & - \\
\hline In1-9b & Indaiá 1 & Spinel harzburgite & Coarse-granular & 73 & 19 & 5 & 3 & 0 & 0 & 0 & 620 & - \\
\hline In1-14a & Indaiá 1 & Spinel lherzolite & Coarse-granular & 76 & 16 & 7 & 1 & 0 & 0 & 0 & 686 & - \\
\hline In1-20b & Indaiá 1 & Spinel harzburgite & Coarse-granular & 87 & 9 & 1 & 0 & 0 & 2 & 0 & 846 & - \\
\hline In $1-24 a$ & Indaiá 1 & Spinel harzburgite & Coarse-granular & 85 & 14 & 0 & 1 & 0 & 0 & 0 & 830 & - \\
\hline In1-34 & Indaiá 1 & Spinel harzburgite & Coarse-granular & 86 & 9 & 3 & 1 & 0 & $<1$ & $<1$ & 813 & - \\
\hline Lm1-20a & Limeira 1 & Spinel harzburgite & Coarse-granular & 85 & 8 & 5 & 1 & 0 & $<1$ & 0 & 833 & - \\
\hline Lm1-36 & Limeira 1 & Spinel harzburgite & Coarse-granular & 82 & 13 & 2 & 3 & 0 & $<1$ & $<1$ & 920 & - \\
\hline In1-1 & Indaiá 1 & Spinel lherzolite & Coarse-porphyroclastic & 68 & 26 & 5 & 0 & 0 & $<1$ & $<1$ & 1057 & - \\
\hline In1-2 & Indaiá 1 & Spinel lherzolite & Coarse-porphyroclastic & 84 & 6 & 7 & $<1$ & 0 & 3 & 0 & 913 & - \\
\hline Lm1-15a & Limeira 1 & Dunite & Coarse-porphyroclastic & 93 & 2 & 3 & $<1$ & 0 & 2 & 0 & 782 & - \\
\hline Lm1-15b & Limeira 1 & Dunite & Coarse-porphyroclastic & 90 & 4 & 3 & 1 & 0 & 3 & 0 & - & - \\
\hline Lm1-17a & Limeira 1 & Spinel lherzolite & Coarse-porphyroclastic & 69 & 22 & 6 & 3 & 0 & 0 & 0 & 849 & - \\
\hline Lm1-20b & Limeira 1 & Spinel harzburgite & Coarse-porphyroclastic & 88 & 8 & 3 & $<1$ & 0 & 0 & 0 & 850 & - \\
\hline Lm1-22 & Limeira 1 & Spinel lherzolite & Coarse-porphyroclastic & 85 & 6 & 7 & $<1$ & 0 & 2 & 0 & 899 & - \\
\hline Lm1-26a & Limeira 1 & Dunite & Coarse-porphyroclastic & 86 & 4 & 3 & 1 & 0 & 5 & 0 & 995 & - \\
\hline Lm1-26b & Limeira 1 & Dunite & Coarse-porphyroclastic & 88 & 4 & 4 & 1 & 0 & 4 & 0 & - & - \\
\hline Lm1-29 & Limeira 1 & Dunite & Coarse-porphyroclastic & 100 & 0 & 0 & $<1$ & 0 & 0 & 0 & - & - \\
\hline
\end{tabular}

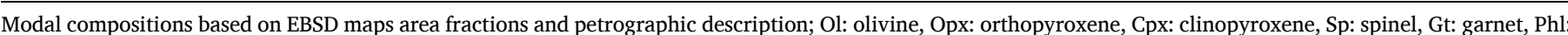
phlogopite, Par: pargasite; \# opx only within keliphitic rims.

$(0.35<$ BA-index $<0.65)$, and (3) fiber-[100], characterized by a point concentration of [100] and distribution of [010] within a girdle orthogonal to [100] (BA-index $>0.65$ ). Consistency between the CPO of olivine and pyroxenes is analyzed based on the dominant slip systems for each mineral. The CPO are considered to be correlated (formed by the same deformation event) when the dominant slip direction and normal to slip planes in the different minerals are parallel: $[100]_{\mathrm{ol}} / /[001]_{\mathrm{opx}} / /$ $[001]_{\mathrm{cpx}}$ and $[010]_{\mathrm{ol}} / /[100]_{\mathrm{opx}} / /[010]_{\mathrm{cpx}}$ (cf., Bascou et al., 2002; Green and Radcliffe, 1972; Frets et al., 2012; Ross and Nielsen, 1978; Tommasi et al., 2000). Pyroxenes CPO with multiple maxima may show partial correlation, with one maxima family aligned with the olivine $\mathrm{CPO}$ and another not.

The automatic grain detection routine in the MTEX toolbox (Bachmann et al., 2010) is used for quantitative analysis of grain sizes and shapes. Grains boundaries were defined by misorientation angles between adjacent pixels higher than $15^{\circ}$. Grains composed of less than 6 pixels as well as grains cut by the limits of the map were not considered in this analysis. We estimate the intracrystalline orientation gradients, which are a proxy of the dislocation density, by the misorientation of each pixel relative to the mean orientation of the grain (M2M). M2M averages over the entire EBSD map are used to quantify the variation in intensity of recrystallization between samples. Low values indicate effective recrystallization, because recrystallized grains have low intracrystalline orientation gradients. The sinuosity of grain shapes is quantified by the shape factor, which is the ratio between the actual perimeter of the grain and the perimeter of a circle with the same area as the grain. The shape factor increases with increasing sinuosity of the grain boundaries. Recrystallization, in particular under static conditions (annealing), where decrease in grain boundary energy is the main driving force for grain boundary migration, should produce a decrease in the shape factor.

\subsection{Modes, mineral compositions, and thermobarometry}

Modal compositions are derived from EBSD mapping over single thin sections. However, many thin-sections are small and the peridotites, often coarse-grained. The modal compositions presented in Table 1 might therefore be biased if the rocks were compositionally heterogeneous at the $\mathrm{mm}$ to $\mathrm{cm}$ scale. Since phlogopite, which is difficult to polish, is often poorly indexed, its modal content may be slightly underestimated.

Major element composition of olivine, orthopyroxene, clinopyroxene, spinel, and garnet were analyzed using a Cameca SX100 electron microprobe at the University of Montpellier. Number of analyzed grains, average compositions, standard deviations, and analytical conditions are presented in the Supplementary Material Table S1. This table also presents mineral compositions previously obtained on the studied xenoliths by Nannini (2016) using a JEOL JXA-8600 eletron microprobe at the Universidade de São Paulo (USP) and by Costa (2008) using a Cameca SX50 electron microprobe at the Universidade de Brasilia (UnB). Equilibrium temperatures were calculated using the Ca-in-opx geothermometer (Brey et al., 1990; revised by Nimis and Grütter, 2010). Equilibrium pressures for the garnet peridotites were calculated using the orthopyroxene-garnet geobarometer of Nickel and Green (1985). As no geobarometer is available for spinel peridotites, equilibrium pressure ranges are estimated based on the absence of plagioclase and of garnet in the studied peridotites, considering their $\mathrm{Cr}$ and $\mathrm{Al}$ contents (Supplementary Information Table S1) and the effect of $\mathrm{Cr}$ on the spinel-garnet phase transition (Ziberna et al., 2013).

The geotherms were calculated for two sets of surface and reduced heat flow: 40 and $20 \mathrm{~mW} / \mathrm{m}^{2}$ for the cratonic geotherm and 50 and 30 $\mathrm{mW} / \mathrm{m}^{2}$ for the warmer geotherm. We used a Moho depth of $42 \mathrm{~km}$, based on receiver function data (Assumpção et al., 2017), thermal conductivities of $2.5 \mathrm{~W} \cdot \mathrm{m}^{-1} \cdot \mathrm{K}^{-1}$ and $3.35 \mathrm{~W} \cdot \mathrm{m}^{-1} \cdot \mathrm{K}^{-1}$ for the crust and 
mantle, respectively, and an exponential decay in heat production with depth with a characteristic length scale of $10 \mathrm{~km}$.

\subsection{Seismic properties}

Seismic properties were calculated using the CPO of all major phases and their respective modal content estimated from EBSD maps (Mainprice et al., 2011). "In situ" seismic properties were estimated using elastic tensors and density of olivine, pyroxenes, and garnet calculated for different pressures and temperatures along the cratonic or the warmer geotherm based on experimentally determined pressure and temperature derivatives (Abramson et al., 1997; Chai et al., 1997a, 1997b; Collins and Brown, 1998). Voigt-Reuss-Hill averaging was applied in all calculations.

The APIP magmatism may have produced heating and metasomatism in the lithospheric mantle. We estimated the effect of heating on the seismic velocities by comparing seismic velocity profiles calculated for an isotropic (random CPO) refractory peridotite (83\% olivine, $12 \%$ orthopyroxene, $5 \%$ clinopyroxene, which is the average composition of the studied spinel peridotites, Table 1) using the two geotherms. We estimated the effect of varying the Fe content in olivine $(\mathrm{Mg} \#=\mathrm{Mg}$ / $(\mathrm{Mg}+\mathrm{Fe}))$ by comparing seismic velocity profiles calculated using elastic constants for olivine with $\mathrm{Mg} \# 93$ (typical cratonic composition)

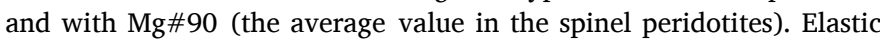
constants for olivine with $\mathrm{Mg \# 93}$ were obtained by interpolating elastic constant data for olivine with $\mathrm{Mg} \# 90$ and Mg\#100 (Abramson et al., 1997; Isaak et al., 1989).

Anelastic effects were not considered in the seismic property calculations. Anelasticity enhances the reduction in seismic velocity associated with a given negative temperature anomaly (Jackson and Faul, 2010). This effect is stronger for long period waves, because the velocity reduction is proportional to the integral of the attenuation at all frequencies above the considered one (Takei, 2017). At temperatures below $1200{ }^{\circ} \mathrm{C}$ anelastic effects are small (Takei, 2017), but for the deepest part of the lithospheric mantle and the asthenosphere, the predictions of reduction in seismic velocities associated with an increase in temperature in the present study are conservative estimates.

\section{Modal compositions}

Refractory, olivine-rich $(>80 \%)$ modal compositions predominate among the spinel peridotites from the Indaiá-1 and Limeira-1 pipes (15/ 21, including 6 dunites; Fig. 2 and Table 1). The remaining spinelbearing peridotites are clinopyroxene-poor lherzolites (4 samples). Only two lherzolites contain $>10 \%$ clinopyroxene. The proportion of orthopyroxene varies between 0 and $36 \%$ and is inversely proportional to the olivine content. 13 spinel peridotites contain $<1 \%$ to $4 \%$ of phlogopite, among which three also contain amphibole $(<1 \%)$.

Canastra-1 xenoliths include 4 garnet peridotites ( 3 lherzolites and 1 harzburgite), 2 garnet clinopyroxenites, 2 garnet websterites, and 2 garnet-free websterites (Fig. 2 and Table 1). All pyroxenites, except one (C-94), contain pargasite. Pargasite contents are exceptionally high in one garnet websterite $(19 \%)$ and in the two garnet-free websterites (12-29\%). Spinel is only present in the kelyphitic coronae around garnet or, in garnet-free websterite C-150, associated with pargasite. Neither the peridotites nor the pyroxenites contain phlogopite.

\section{Microstructures}

\subsection{Canastra-1 xenoliths}

\subsubsection{Garnet peridotites}

The garnet peridotites have fine-porphyroclastic microstructures (Table 1) characterized by coarse porphyroclasts of olivine, ortho- and clinopyroxene, and garnet (2-10 mm wide) surrounded by a matrix of fine-grained olivine with grain sizes ranging from 200 to $500 \mu \mathrm{m}$

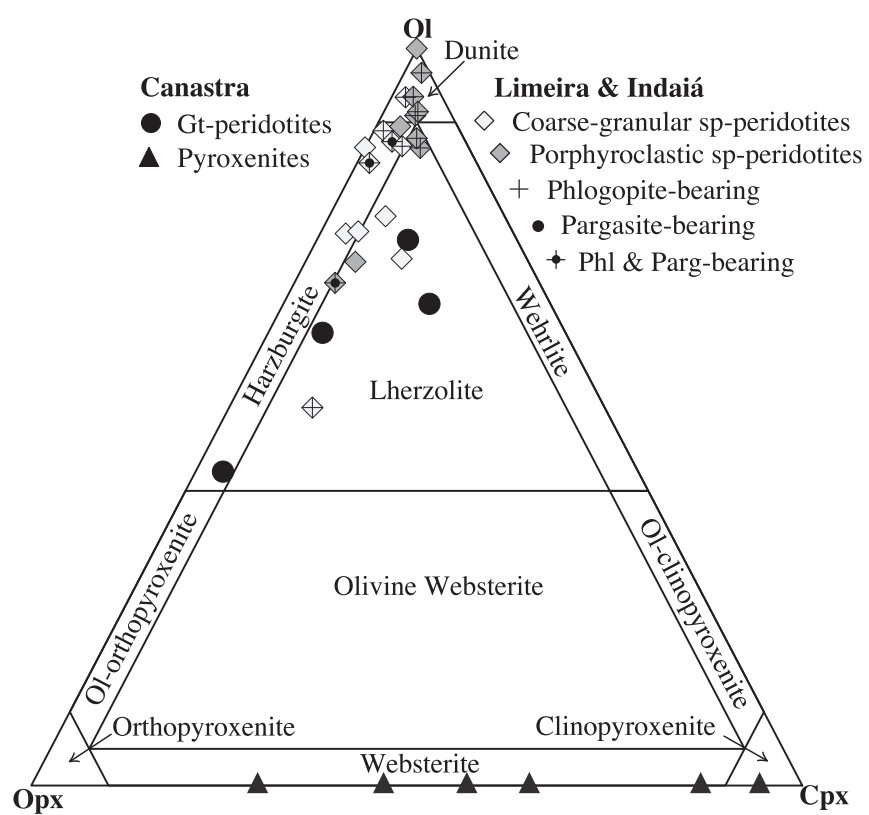

Fig. 2. Modal compositions (recalculated to a $100 \%$ olivine-orthopyroxeneclinopyroxene assemblage).

(Figs. 3a,b and 4a). This matrix composes 40-60 area \% of the samples. The olivine neoblasts in the matrix exhibit dominantly polygonal shapes with $120^{\circ}$ triple junctions and do not display intracrystalline deformation features. Some garnet-peridotites have olivine porphyroclasts up to $10 \mathrm{~mm}$ wide. These porphyroclasts have irregular shapes, display undulose extinction and closely spaced subgrains boundaries, and are partially replaced by recrystallized grains (Fig. 3a). In other samples, olivine is fully recrystallized (Fig. 3b), leading to low average intragranular misorientation and shape factor values at the thin section scale (Fig. 4b,c). Orthopyroxene porphyroclasts occur either associated with garnet and diopside or isolated (Fig. 3a,b). They have mainly curved grain boundaries and irregular, but slightly elongated shapes marking the foliation (Fig. 3a). Orthopyroxene porphyroclasts may also display angular shapes (Fig. 3b). In both cases, they present undulose extinction and kink bands (white arrows in Fig. 3b) and are locally partially recrystallized to very fine grain sizes (70-80 $\mu \mathrm{m}$; black arrow in Fig. 3b). Clinopyroxene porphyroclasts have irregular to rounded shapes with gently curved grain boundaries and often display undulose extinction (Fig. 3a,b). Garnet porphyroclasts are generally smaller than the other minerals (mean diameter of $2 \mathrm{~mm}$ ). They are systematically surrounded by kelyphitic coronae of variable thickness composed of tiny grains of orthopyroxene, clinopyroxene, phlogopite and spinel (Fig. 3a,b). Garnet is mainly rounded, but it may show a weak elongation parallel to the pyroxenes elongation (Fig. 3a).

\subsubsection{Pyroxenites}

Garnet clinopyroxenites present a coarse-granular microstructure (Table 1). They are composed of $2-7 \mathrm{~mm}$ wide rounded to polygonal garnet grains with kelyphitic coronae of variable width intercalated with irregularly shaped clinopyroxenes (Fig. 3c). Clinopyroxenes have curved grain boundaries (Fig. 3c); some grains show undulose extinction and, more rarely, subgrains. The clinopyroxenes also present spongy rims, recording limited partial melting during extraction.

Garnet-bearing websterites also have a coarse-granular microstructure, with grain sizes of 1-2 $\mathrm{mm}$ on average. They often display a rough foliation marked by elongated garnet aggregates (S in Fig. 3d). Garnet crystals have irregular shapes and are sometimes slightly elongated parallel to the foliation. They do not display kelyphitic coronae. Pyroxenes have irregular shapes, but, locally, grain boundaries may be straight and form $120^{\circ}$ triple junctions. Orthopyroxene contains kinks 

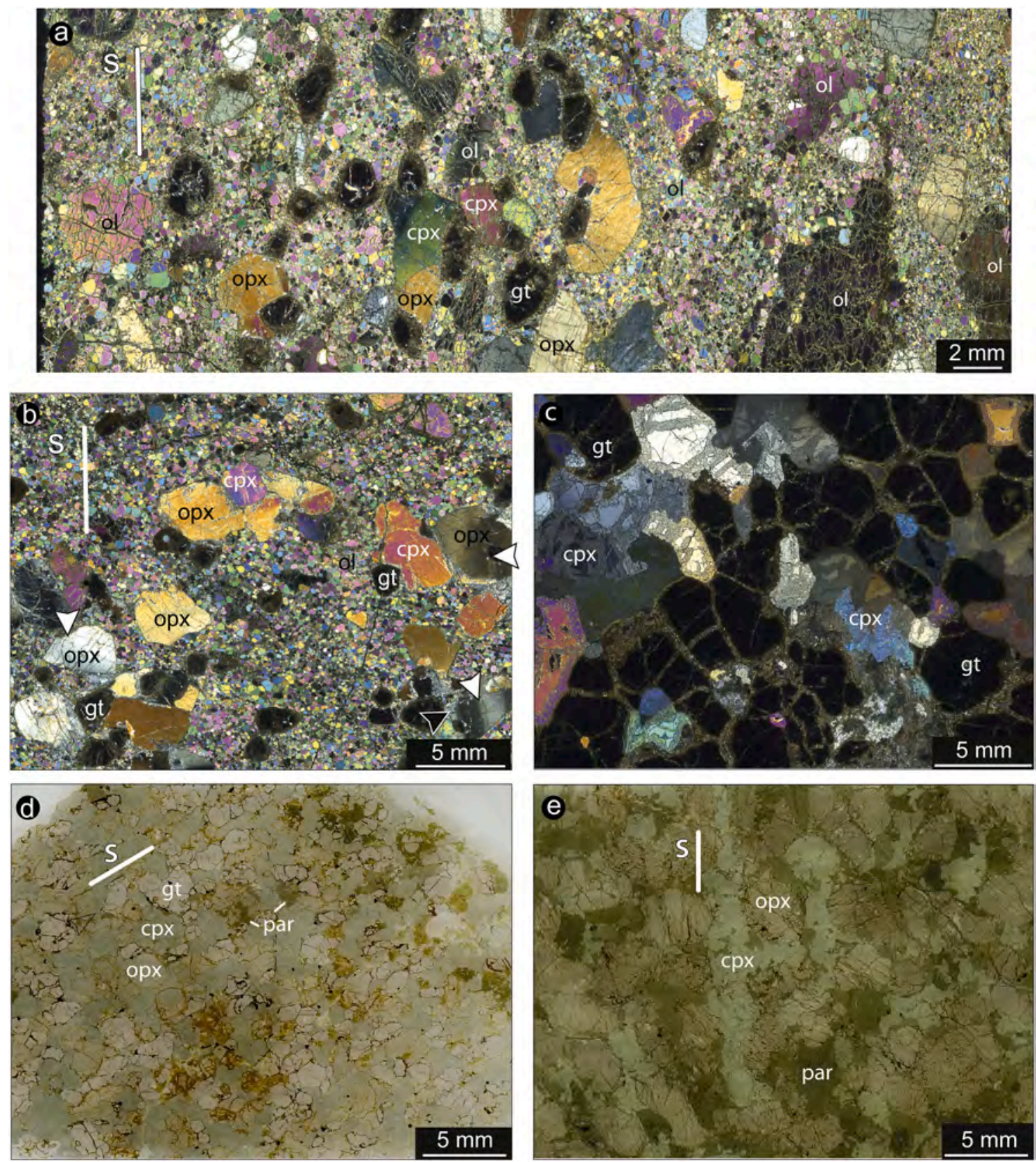

Fig. 3. Typical microstructures of the Canastra- 1 mantle xenoliths. (a) Partially recrystallized garnet-peridotite C-100, characterized by the coexistence of coarse olivine (ol) and ortho- and clinopyroxene crystals (opx, cpx) with irregular shapes, rounded garnet (gt) crystals, and a matrix of fine polygonal olivine crystals. (b) Garnet-peridotite C-106, in which olivine is fully recrystallized. (c) Coarse-granular garnet-clinopyroxenite C-147. (d) Coarse-granular garnet-websterite C-203 with minor pargasite (par); (e) Coarse-porphyroclastic amphibole-websterite C-127. (a,b,c) Cross-polarized and (d,e) natural light microphotographs. S outlines the compositional banding in (d) and (e).

and undulose extinction. Clinopyroxene also displays undulose extinction and subgrains and locally forms aggregates composed of polygonal strain-free crystals with slightly smaller sizes ( $0.5 \mathrm{~mm}$ on average).

Garnet-free websterites display coarse-porphyroclastic microstructures (Table 1). They present a rough compositional layering marked by alternating ortho- and clinopyroxene-rich lenses (S in Fig. 3e). Orthopyroxene is coarse grained with sinuous grain boundaries. It displays undulose extinction and kink bands and often contains exsolutions. Clinopyroxene has a bimodal grain size distribution, with coarse grains (up to $3 \mathrm{~mm}$ wide) with irregular shapes and undulose extinction and smaller polygonal strain-free crystals $(0.3 \mathrm{~mm}$ on average).

In both garnet-bearing and garnet-free websterites, amphibole (Fig. 3d,e) often replaces the pyroxenes. The amount of replacement varies from sample to sample (Table 1), either forming local amphibolerich patches (Fig. 3d) or being pervasive at sample scale (Fig. 3d,e). Spinel occurs as small crystals $(<0.1 \mathrm{~mm})$ associated with amphibole in garnet-free websterite $\mathrm{C}-150$ or in the kelyphitic coronae in garnetclinopyroxenites.

\subsection{Limeira-1 and Indaiá-1 spinel peridotites}

The spinel peridotites from the Limeira- 1 and Indaiá-1 pipes were classified in two categories: porphyroclastic and coarse-granular, according to the olivine grain morphology, mainly the sinuosity of olivine grain boundaries, which was quantified using the shape factor (Fig. 4 and Table 1). Porphyroclastic peridotites are characterized by olivine 

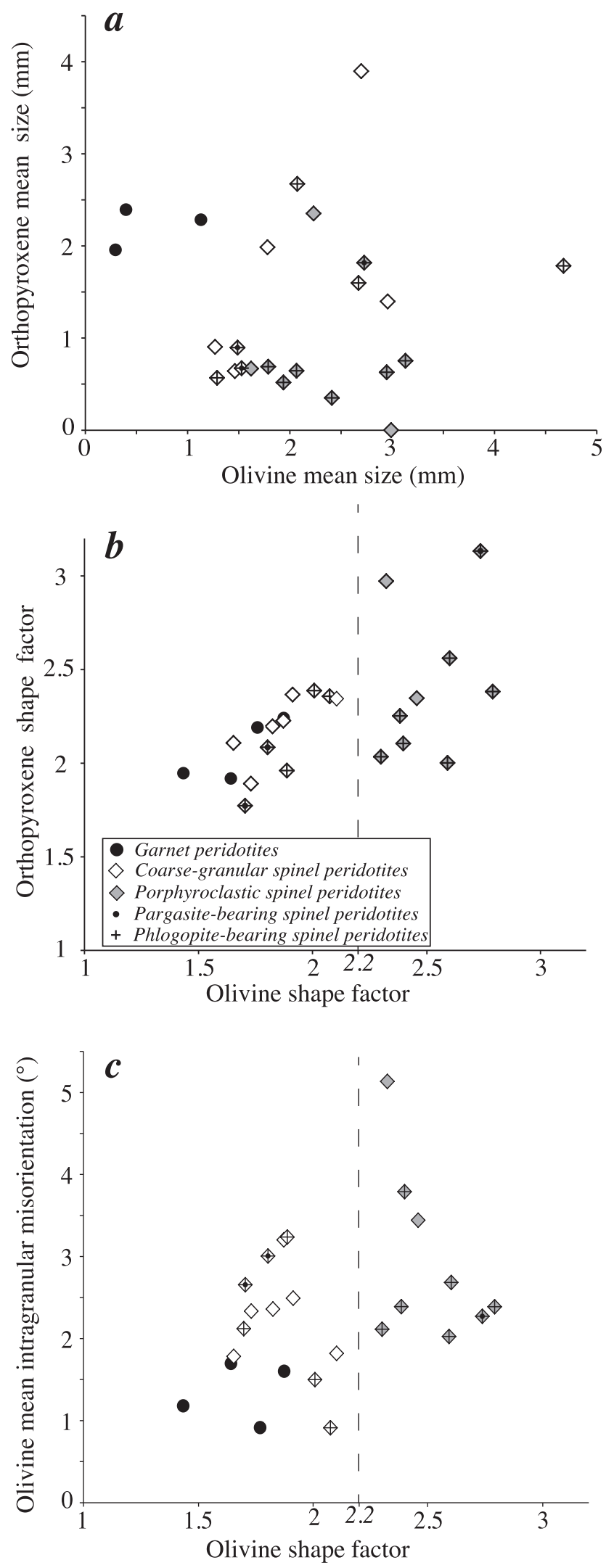

Fig. 4. (a) Mean grain size of olivine vs. mean grain size of orthopyroxene. (b) Mean olivine shape factor vs. mean orthopyroxene shape factor. (c) Mean shape factor vs. mean intragranular misorientation in olivine. All data are apparent (2D) values (no stereological corrections) derived from EBSD data weighted by grain area. Microstructural data for all samples is presented in Supplementary Material Table S2. crystals with sinuous grain boundaries, whereas coarse-granular peridotites tend to display more polygonal olivine grain shapes. There is a continuous variation between these two microstructures. However, for descriptive purposes, we defined an arbitrary limit between the two groups at an olivine shape factor of 2.2. Coarse-granular microstructures (shape factor $<2.2)$ predominate among Indaiá-1 peridotites $(9 / 11)$, whereas porphyroclastic microstructures (shape factor $>2.2$ ) predominate among Limeira-1 peridotites (8/10).

\subsubsection{Coarse-granular spinel peridotites}

This group contains medium- to coarse-grained peridotites (Fig. 4a) with compositions ranging from dunite to orthopyroxene-rich lherzolite (Fig. 2 and Table 1). Phlogopite and amphibole are rare in this group; they are observed only as accessory minerals $(\leq 1 \%)$ in four harzburgites (Table 1). Olivine crystals show dominantly straight grain boundaries, locally forming polygonal shapes (Fig. 5a,b,c,d). Coarse-granular peridotites are therefore characterized by low average olivine shape factors $(<2.2$; Fig. 4b,c). A single peridotite in this group - Lm1-20a - displays a strong shape-preferred orientation (SPO) of olivine, orthopyroxene, and spinel, leading to a tabular microstructure (Fig. 5a,b). The remaining samples show no clear olivine SPO (Fig. 5c,d). A large proportion of olivine is free of internal deformation features (Fig. 5b,d). However, some grains display undulose extinction or widely spaced subgrain boundaries (black arrow in Fig. 5d). This results in dispersion of the average olivine M2M values (Fig. 4c): two coarse-granular peridotites yield M2M as low as the strongly recrystallized garnet-peridotites from Canastra-1, but other coarse-granular peridotites have higher M2M values (2-3.2 $2^{\circ}$ that overlap with the lower range of M2M values of the porphyroclastic spinel peridotites.

Orthopyroxenes have irregular shapes with gently curved grain boundaries (Fig. 5a,c). They locally display cuspate terminations at orthopyroxene-olivine contacts (white arrows in Fig. 5c). These pyroxene shapes are associated with shape factors $<2.5$. Clinopyroxene is usually finer grained and has more irregular shapes than orthopyroxene (Fig. 5a,c). In many samples, the clinopyroxene has a clear interstitial habitus (Fig. 5a,c). Spinel is fine- to medium-grained and has amoeboid shapes, sometimes containing rounded olivine inclusions (white arrow in Fig. 5d). Phlogopite and pargasite, when present, occur dispersed in the rock as small crystals with interstitial habitus or associated with orthopyroxene.

\subsubsection{Porphyroclastic spinel peridotites}

This group is composed of dunites, harzburgites, and clinopyroxenepoor lherzolites, but highly refractory compositions predominate (Fig. 2). All porphyroclastic spinel peridotites are coarse-grained and most contain phlogopite and/or amphibole as accessory minerals (Fig. 2 and Table 1). They are dominantly composed of coarse olivine crystals with irregular shapes and sinuous grain boundaries (Fig. 5e,f,g,h). Areaweighted average olivine grain sizes range between 1.5 and $3.2 \mathrm{~mm}$ (Fig. 4a), but coarser grains may attain up to $10 \mathrm{~mm}$. In several porphyroclastic peridotites, olivine-olivine contacts are sinuous, but the wavelength of the grain boundary sinuosity $(<100 \mu \mathrm{m})$ is small when compared to the grain size $(\mathrm{mm})$ and $120^{\circ}$ triple junctions (black arrows in Figs. 5f, h) are observed despite the sinuosity of the boundaries, suggesting that grain shapes were initially polygonal. These coarse olivine crystals are locally rimmed by neoblasts with sizes similar to the wavelength of sinuosity of the grain boundaries $(<100 \mu \mathrm{m}$, Figs. $5 \mathrm{~g}, \mathrm{~h}$ and white arrows in 6). Coarse olivine crystals often display undulose extinction and subgrains (white arrows in Figs. 5f,h), but no clear SPO. Average M2M values for olivine in this group range between 2 and $5^{\circ}$, being on average higher, but partially overlapping those of coarsegranular peridotites (Fig. 4c).

Orthopyroxene usually displays very irregular grain shapes (Fig. 5e,f, $\mathrm{g}, \mathrm{h}$ ), which are associated with shape factors ranging from 1.8 to 3.2 (Fig. 4b). Orthopyroxene grain sizes are on average smaller than that of olivine (Fig. 4a), but they may be highly variable within each sample. 

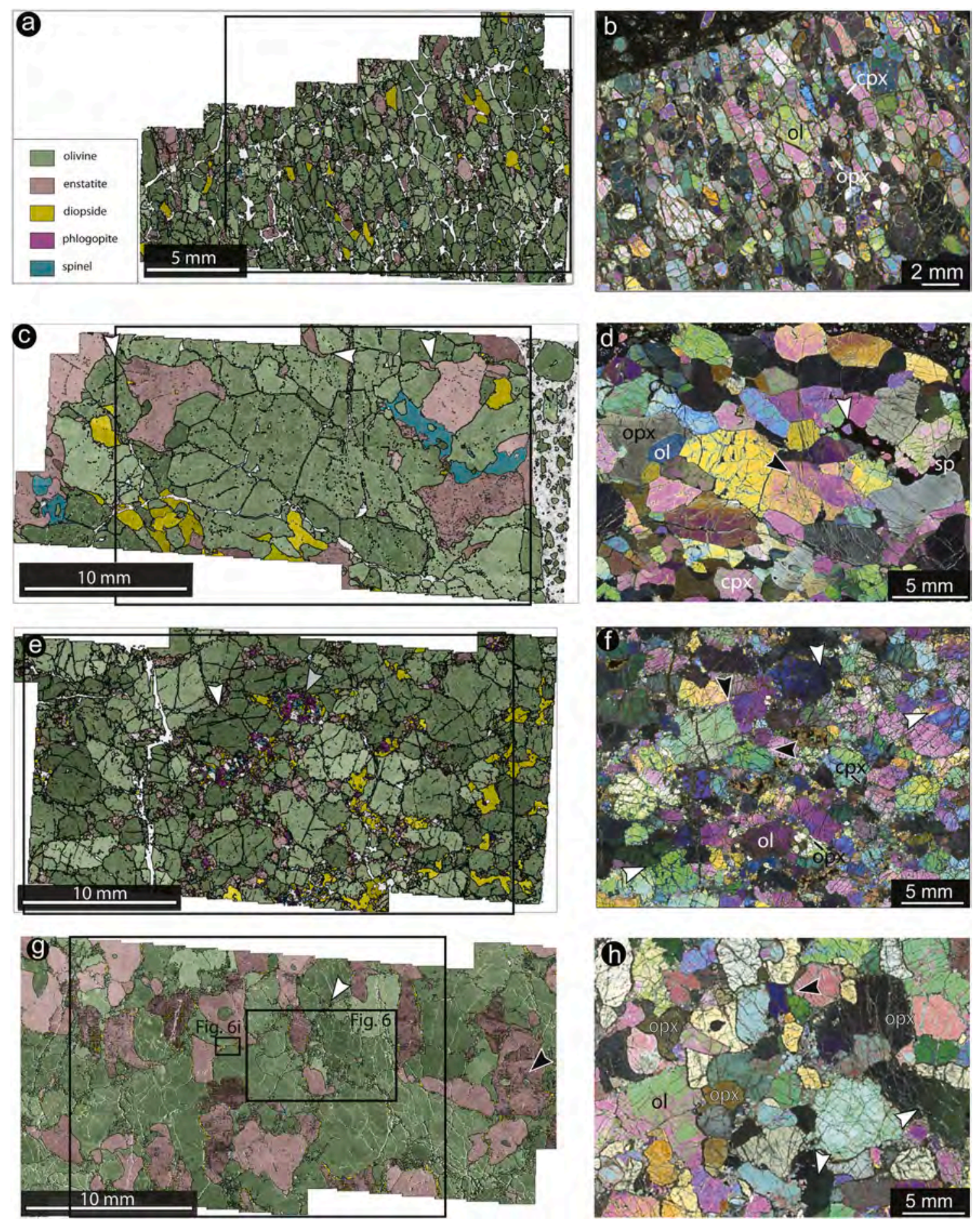

Fig. 5. Typical microstructures of the Limeira-1 and Indaiá-1 spinel-peridotites. (a,c,e,g) EBSD phase maps showing the shapes and spatial distribution of the different mineral phases. (b,d,f,h) Thin section-scale photomicrographs in cross-polarized light of the domains marked by a rectangle onto the EBSD maps. (a,b) Coarse-granular spinel peridotite Lm1-20a, which is characterized by a strong preferred orientation of tabular olivine crystals and interstitial pyroxenes with cuspate termination and curved grain boundaries. (c,d) Coarse-granular spinel peridotite In1-9b characterized by coarse polygonal olivine crystals with rare subgrains (black arrow in d), coarse orthopyroxene with irregular shapes, gently curved grain boundaries, and local cuspate terminations (white arrows in c), interstitial clinopyroxene, and interstitial spinel with rounded olivine inclusions (white arrow in d). (e,f) Coarse porphyroclastic lherzolite In1-2 characterized by irregularly shaped olivine with strong undulose extinction (white arrows in $\mathrm{f}$ ) and planar subgrain boundaries and a domanial distribution of ortho- and clinopyroxene forming seams of crystals with interstitial shapes along olivine grain boundaries (best seen in e), and pockets of phlogopite, pyroxenes and spinel (gray arrow in e). (g,h) Coarse porphyroclastic harzburgite In1-1 composed of coarse olivine crystals with sinuous grain boundaries lined by very fine-grained neoblasts (white arrows in g), locally forming $120^{\circ}$ triple junctions (black arrow in $\mathrm{h}$ ) and coarse irregularly-shaped orthopyroxenes rimmed by fine-grained clinopyroxene and containing rounded olivine inclusions (black arrow in g). Olivine porphyroclasts have undulose extinction and subgrains (white arrows in h). 
Coarse orthopyroxene grains often show undulose extinction and kink bands. Cuspate terminations and embayments at orthopyroxene-olivine contacts and rounded olivine inclusions (black arrow in Fig. 5g) are common. Orthopyroxene also occurs as medium-size crystals with interstitial habitus, which form pyroxene-rich seams with irregular shapes along olivine grain boundaries (Fig. 5e). Aggregates of ortho-, clinopyroxene, and spinel, which might be derived from former garnets, are observed locally.

Clinopyroxene in the harzburgites and dunites often only occurs as very fine-grained aggregates (grains are $\sim 100 \mu \mathrm{m}$ wide) accompanied by minor spinel, which rim (yellow arrows in Fig. 6) or fill fractures across orthopyroxene crystals. Otherwise, clinopyroxene is mediumgrained and has dominantly interstitial shapes (Fig. 5e,f). The clinopyroxene forms aggregates with orthopyroxene or spinel that delineate an anastomosed network across the sample (Fig. 5e). It may also be concentrated in patches with orthopyroxene and/or spinel or occur as isolated interstitial grains. In some clinopyroxene-rich harzburgites, like Lm1-26b, clinopyroxene occurs both as fine-grained aggregates rimming orthopyroxene and as isolated grains with interstitial shapes.

Phlogopite occurs either dispersed in the rock as crystals with interstitial habitus or in plurimilimetric pockets, often associated with pyroxenes and spinel (gray arrow in Fig. 5e). Amphibole occurs as rare small grains associated with pyroxenes.

\section{Mineral compositions}

Modal content of olivine in the presently studied mantle xenoliths is coherent with that in cratonic mantle xenoliths worldwide. However, olivine is often richer in $\mathrm{Fe}$, displaying lower $\mathrm{Mg} \#$ (molar $\mathrm{Mg} / \mathrm{Mg}+$ $\mathrm{Fe})$ ), especially in samples displaying porphyroclastic microstructures (Fig. 7a). Olivine in the garnet peridotites yields $\mathrm{Mg \#}$ of $\sim 90$, a value coherent with those of peridotites with similar fine-porphyroclastic microstructures derived from the deep lithospheric mantle in other cratons (e.g., Boyd and Mertzman, 1987; Pearson et al., 2003; Baptiste et al., 2012). The spinel peridotites record important variations of the

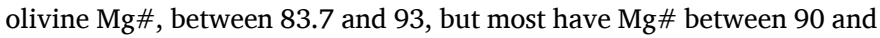
93, consistent with data from other cratons (Fig. 7a). There is no linear correlation between the olivine $\mathrm{Mg \#}$ and modal proportion, but all porphyroclastic peridotites with Fe-rich olivine $(\mathrm{Mg} \#<89)$ contain $>80 \%$ modal olivine (Fig. 7a). The lowest olivine Mg\# (83.7) is, however, displayed by the coarse-granular peridotite In1-6, which has an abnormally low olivine modal content for a peridotite (49\%), indicating melt-rock reactions crystallizing pyroxenes. Most Fe-rich peridotites

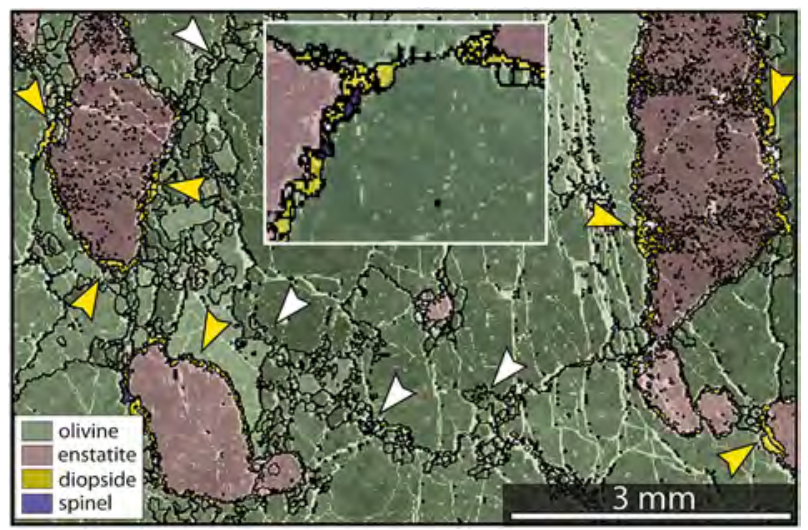

Fig. 6. Detail of Fig. $5 \mathrm{~g}$ showing coarse olivine crystals lined by fine-grained neoblasts (white arrows) and coarse irregularly-shaped orthopyroxenes rimmed by fine-grained clinopyroxene and minor spinel (yellow arrows). Insert displays an enlargement of the clinopyroxene-spinel rims (same sample, but domain outside the field of view of the main image, indicated as Fig. $6 \mathbf{i}$ in Fig. 5g). (For interpretation of the references to colour in this figure legend, the reader is referred to the web version of this article.) contain modal phlogopite (Fig. 7a), but phlogopite is also present in some spinel peridotites with Mg-rich olivine (Mg\# > 91) (Table 1).

$\mathrm{Ni}$ content in olivine varies between 2750 and $3500 \mathrm{ppm}$, which are the values observed in olivine from cratons worldwide (Fig. 8a). The only exception is the coarse-granular lherzolite In1-6, which has a very low Ni content (1857 ppm). There is no systematic correlation between the composition of olivine and the microstructure of the peridotites, but coarse-granular spinel peridotites display more homogeneous Ni contents and $\mathrm{Mg} \#$ in olivine than porphyroclastic spinel peridotites (Fig. 8a). Ca content in olivine is usually $<350 \mathrm{ppm}$, but the garnetperidotites and the spinel peridotites In1-1 and Lm1-29 contain olivine exceptionally rich in Ca ( $>500$ ppm; Fig. 8b). Porphyroclastic spinel peridotites yield, on average, higher Ca contents in olivine (Fig. 8b).

The $\mathrm{Mg} \#$ of orthopyroxene varies between 87 and 94 in spinel peridotites and between 90 and 93 in garnet peridotites (Fig. 7b, 8c). The $\mathrm{Mg} \#$ of clinopyroxene varies between 88 and 95 in spinel peridotites and between 91 and 94 in garnet peridotites (Fig. 7c, 8e). There is no correlation between modal content of ortho- or clinopyroxene and their $\mathrm{Mg} \#$ or between the pyroxenes $\mathrm{Mg} \#$ and the microstructural type or the presence of phlogopite (Fig. $7 \mathrm{~b}, \mathrm{c}$ ). However, the $\mathrm{Mg \#}$ of olivine and orthopyroxene are positively correlated, suggesting equilibrium (Fig. 8c). The data are aligned close to the correlation line 1:1, with the $\mathrm{Mg} \#$ of orthopyroxene usually slightly higher than $\mathrm{Mg} \#$ of olivine, especially in the spinel peridotites containing phlogopite and in the garnet peridotites (Fig. 8c). These observations are coherent with those in peridotite xenoliths from cratons worldwide (Fig. 8c).

The Mg\# of clinopyroxene also displays a positive correlation with

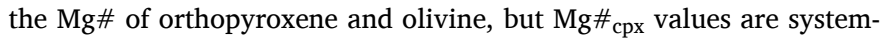
atically higher than that of olivine, suggesting disequilibrium between these minerals (Fig. 8e). The present data are coherent with observations in other cratons, but plot predominantly in the upper limit of $\mathrm{Mg}$ enrichment of clinopyroxene relative to olivine (Fig. 8e). Most presently studied peridotites plot close or slightly above the $\mathrm{Fe}-\mathrm{Mg}$ equilibrium between olivine and clinopyroxene in troctolites (Lissenberg and Dick, 2008).

$\mathrm{TiO}_{2}$ content in orthopyroxene from porphyroclastic spinel peridotites is highly variable, ranging from $<0.05 \mathrm{wt} \%$ to $0.2 \mathrm{wt} \%$. The range of variation is smaller in the coarse-granular peridotites, which have orthopyroxenes with $\mathrm{TiO}_{2}$ content $<0.13 \mathrm{wt} \%$ (Fig. 8d). In garnet peridotites, orthopyroxenes have $\mathrm{TiO}_{2}$ contents between 0.13 and $0.15 \mathrm{wt}$ $\%$. There is no clear correlation between orthopyroxene $\mathrm{TiO}_{2}$ content and $\mathrm{Mg} \#$, but the highest $\mathrm{TiO}_{2}$ contents are associated with the lowest $\mathrm{Mg} \#$ (Fig. 8d). $\mathrm{TiO}_{2}$ content in clinopyroxene is also variable, attaining $0.35 \mathrm{wt} \%$ (Fig. 8f). There is a rough inverse correlation between the $\mathrm{TiO}_{2}$ content and $\mathrm{Mg} \#$ in clinopyroxene (Fig. 8f). Clinopyroxene in phlogopite-bearing spinel-peridotites and garnet-peridotites displays, on average, higher $\mathrm{TiO}_{2}$ contents, but high $\mathrm{TiO}_{2}$ contents are also documented in some phlogopite-free coarse-granular spinel peridotites (Fig. 8f). The $\mathrm{TiO}_{2}$ content of both pyroxenes in the present study covers almost the entire range observed in cratonic mantle xenoliths worldwide (Fig. 8d,f).

The $\mathrm{Cr} \#(\mathrm{Cr} \#=\mathrm{Cr} /(\mathrm{Cr}+\mathrm{Al}))$ of spinel in the presently studied spinel peridotites varies between 10 and 95 (Fig. 8g). All phlogopite-free spinel peridotites plot along the olivine spinel mantle array (OSMA, Arai, 1987). However, half of the studied phlogopite-bearing porphyroclastic spinel peridotites plot out of the OSMA (Fig. 8g), an evidence for chemical disequilibrium between the two phases. Most of these phlogopite-bearing porphyroclastic spinel peridotites contain chromite $(\mathrm{Cr} \#>80$ ) associated with olivine with variable $\mathrm{Mg \#}$ (between 85 and 92), but the dunite Lm1-29 contains spinel with low $\mathrm{Cr} \#$ and olivine with high $\mathrm{Mg} \#$ (Fig. 8g). The $\mathrm{TiO}_{2}$ content of spinel in coarse-granular spinel peridotites is usually $<0.5 \mathrm{wt} \%$. It is more variable in the porphyroclastic spinel peridotites, where it may attain $>4 \mathrm{wt} \%$ (Fig. $8 \mathrm{~h}$ ). Spinels enriched in $\mathrm{TiO}_{2}$ have low $\mathrm{Mg} \#$, but low $\mathrm{Mg} \#$ spinel may display low $\mathrm{TiO}_{2}$ content. 

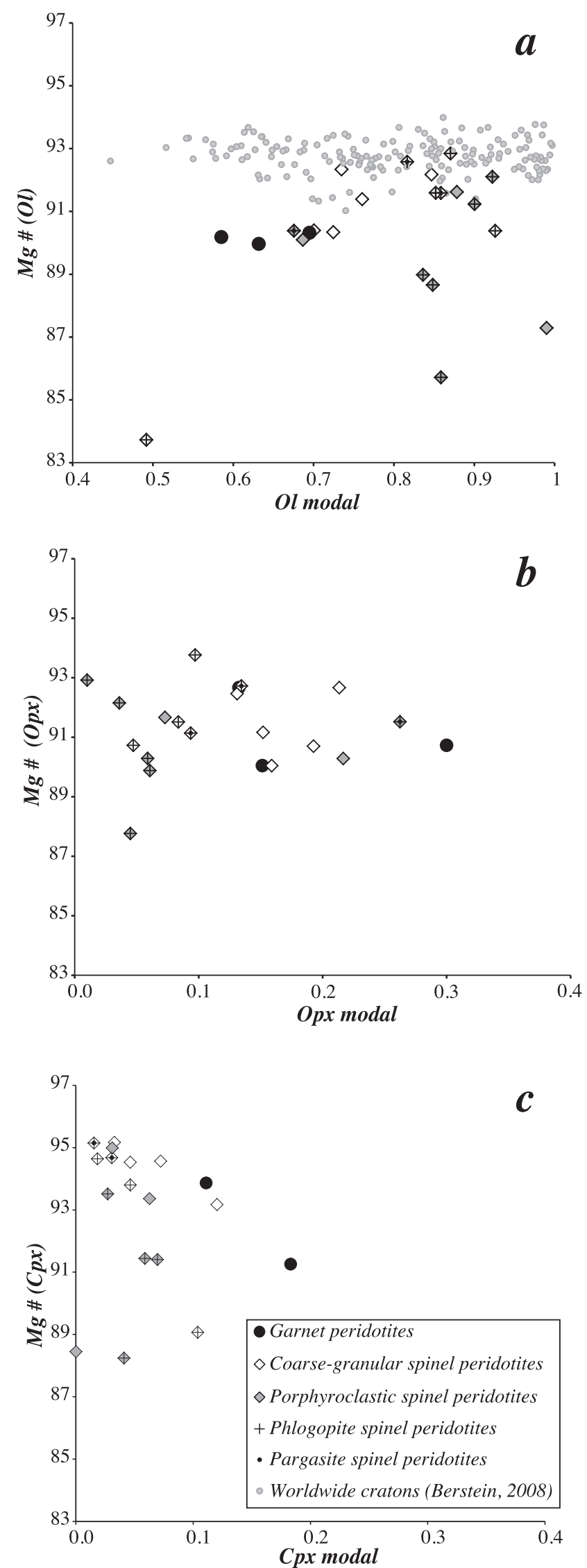

Fig. 7. Modal content vs. $\mathrm{Mg} \#(\mathrm{Mg} /(\mathrm{Mg}+\mathrm{Fe})$, atomic ratio) of (a) olivine, (b) orthopyroxene, and (c) clinopyroxene. For comparison, a compilation of olivine contents and Mg\# in cratons worldwide by Bernstein et al. (2007) is presented in (a). 

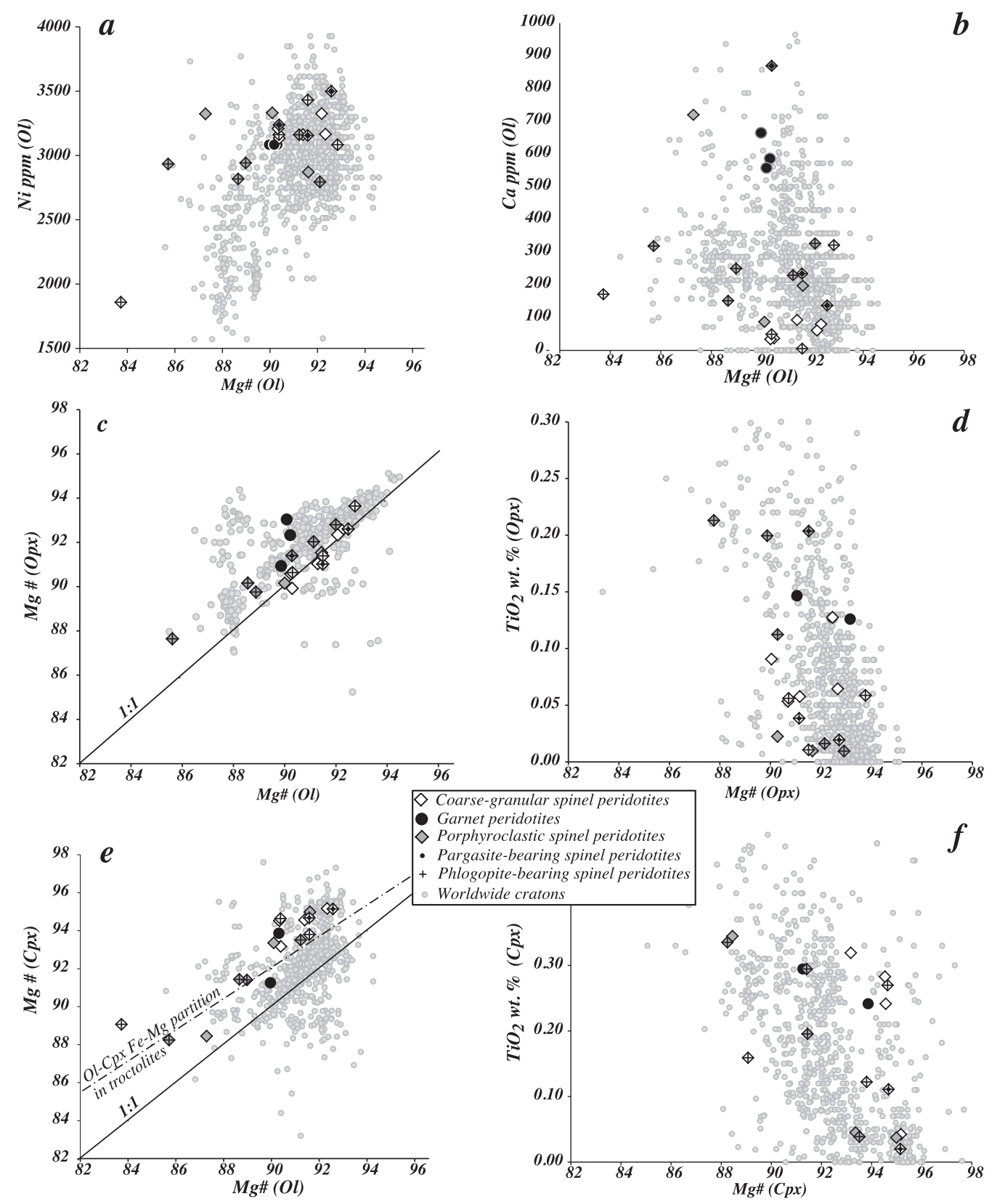

Porphyroclastic spinel peridotites

Pargasite-bearing spinel peridotites

Phlogopite-bearing spinel peridotites
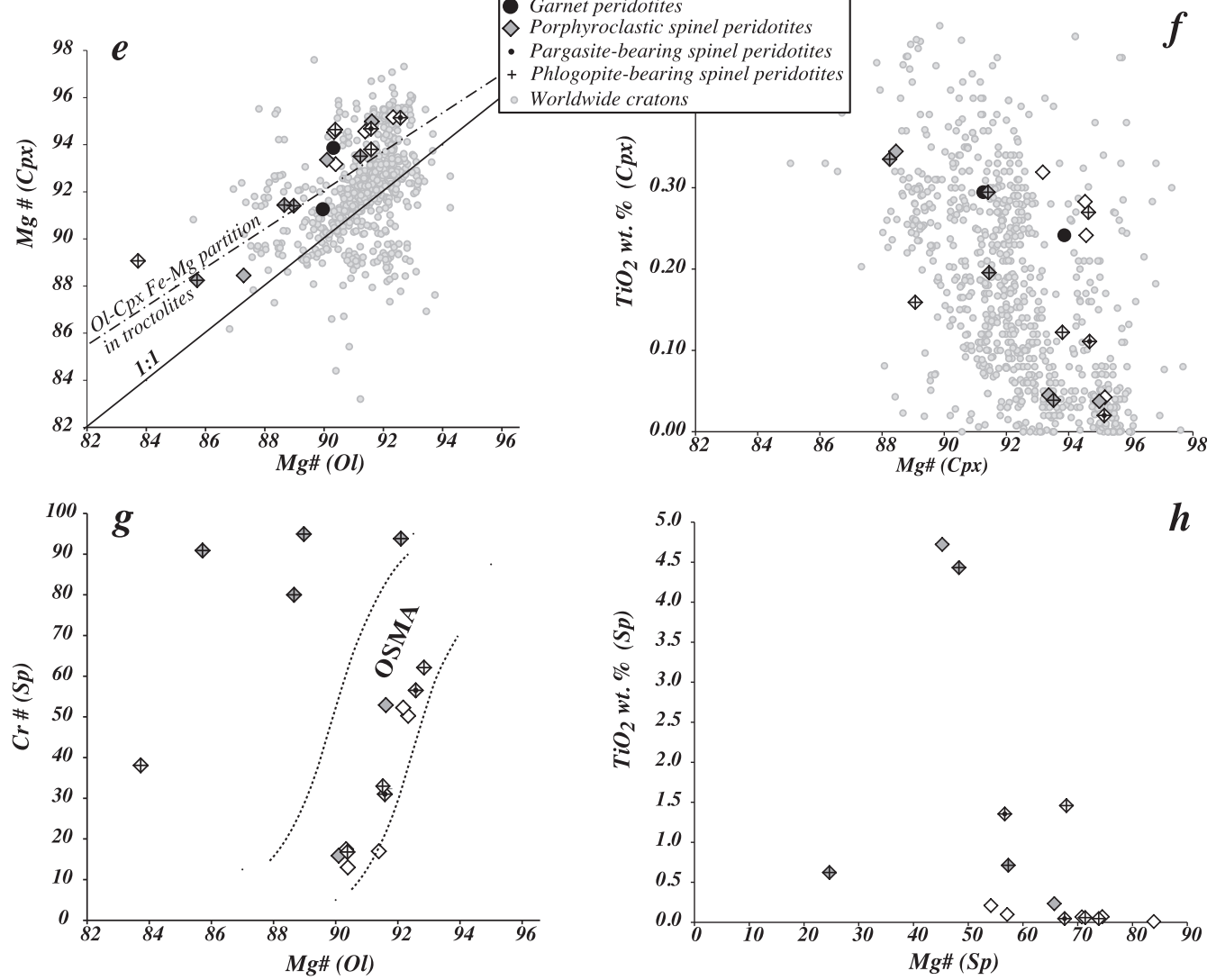

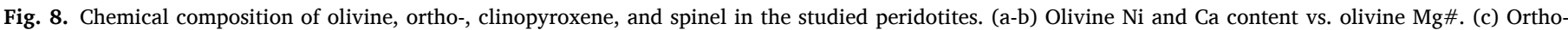

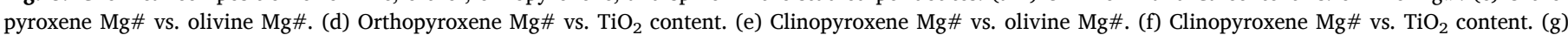

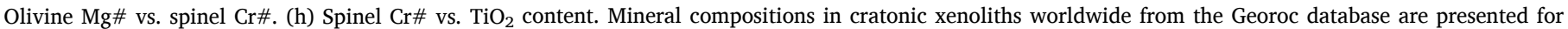
comparison in (a-f). Fe-Mg partition in troctolites from Lissenberg and Dick (2008) is plotted in (e). OSMA array (Arai, 1987) is plotted in (g). 


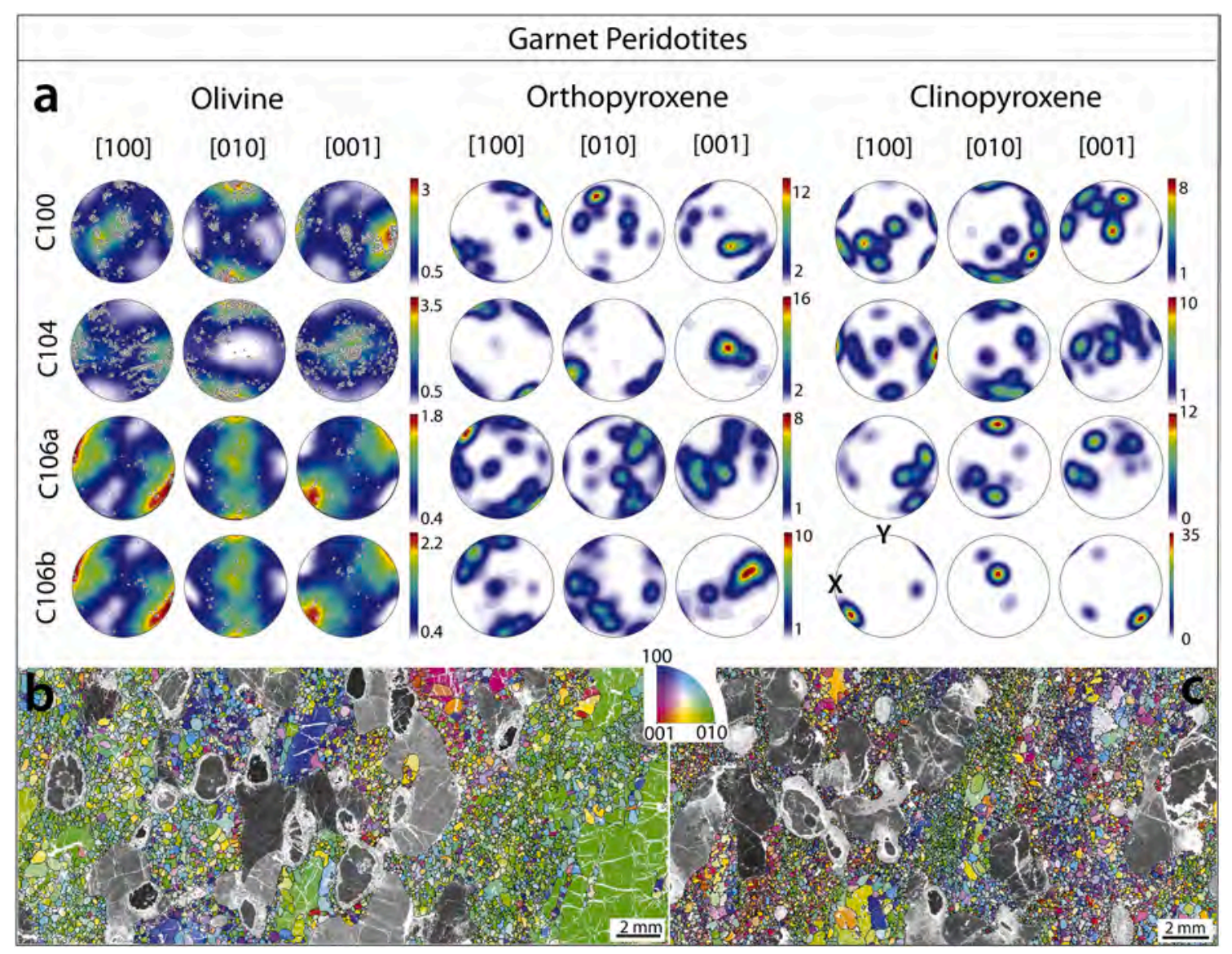

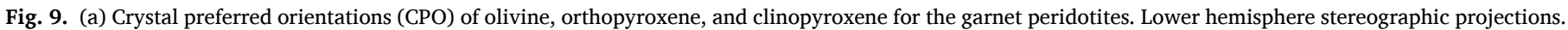

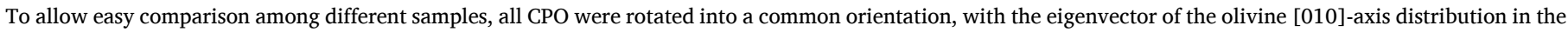

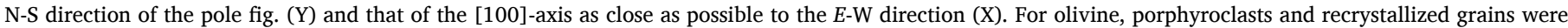

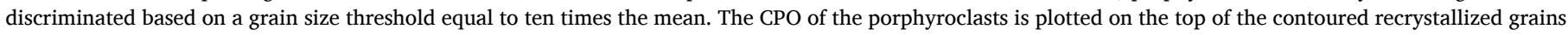

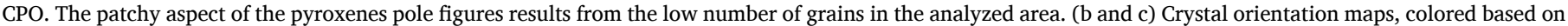

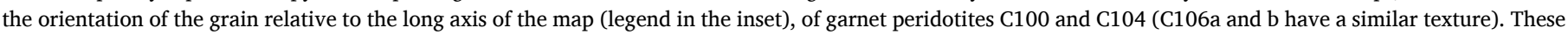

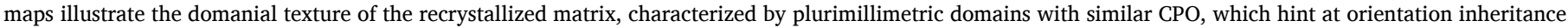
from an originally coarse-grained microstructure.

Garnet in garnet peridotites is pyrope, with $\mathrm{Mg} \#$ between 83.7 and 85.9, $\mathrm{TiO}_{2}$ contents ranging from 0.5 to $0.7 \mathrm{wt} \%$, and $\mathrm{Cr}_{2} \mathrm{O}_{3}$ contents between 1.9 and $2.7 \mathrm{wt} \%$.

\section{Crystallographic preferred orientations}

\subsection{Garnet peridotites}

The strength of the olivine CPO in the garnet peridotites depends on the intensity of recrystallization. $\mathrm{C} 100$, which preserves a few coarse olivine porphyroclasts, has a moderate intensity CPO with an orthorhombic symmetry. The strong [100] and [001] point maxima in Fig. 9 correspond to the porphyroclasts. The other garnet peridotite samples, which are almost fully recrystallized, have weaker olivine CPO (Fig. 9a). A notable feature of the olivine CPO in these samples is that the [001] maximum is similar or even stronger in intensity than the [100] one (Fig. 9a). Analysis of olivine orientation maps for the four garnet peridotites highlights a domanial texture, characterized by domains in which recrystallized olivine grains display a similar CPO, sometimes coherent with the orientation of remaining portions of porphyroclasts, but that is markedly different than the CPO of the neighboring domains (Figs. 9b,c).

Even though the CPO of orthopyroxenes is poorly defined in the garnet peridotites due to the small amount of crystals, there is a tendency of the $[001]_{\mathrm{opx}}$ maximum to be at low angle to the $[001]_{\mathrm{ol}}$ maximum (Fig. 9a). The CPO of the clinopyroxenes is even more poorly defined than that of orthopyroxene, as the number of grains in a thin section is smaller. Nevertheless, in sample C104, which contains more clinopyroxene grains, the clinopyroxene $\mathrm{CPO}$ is characterized by alignment of the $[100]_{\mathrm{cpx}}$ and $[010]_{\mathrm{cpx}}$ maxima with the olivine $[100]_{\mathrm{ol}}$ and $[010]_{\mathrm{ol}}$ maxima, respectively.

\subsection{Spinel peridotites}

Olivine CPO in the spinel peridotites is usually stronger than in the garnet peridotites (Fig. 10). The J-indexes vary between 1.6 and 9. Most samples have J-indexes $>2.5$, corresponding to moderate to strong CPO. However, all samples with J-index $>7$ are very coarse grained. In these samples $\leq 100$ olivine grains could be measured, what results in overestimation the J-index (Ben and Mainprice, 1998). Most samples have olivine $\mathrm{CPO}$ with an orthorhombic symmetry, characterized by three roughly orthogonal maxima of [100], [010], and [001] with systematically stronger concentrations of [100] and [010] relative to [001] (Figs. 10 and 11). Some samples show some dispersion of [100] and [001] in the plane normal to the [010] maximum, that is, an axial-[010] tendency (Fig. 11). Olivine CPO with tendency to axial-[100] symmetry, characterized by a point maximum of [100] and incomplete girdles of [010] and [001] normal to it, is rare (Figs. 10 and 11). Coarse granular 


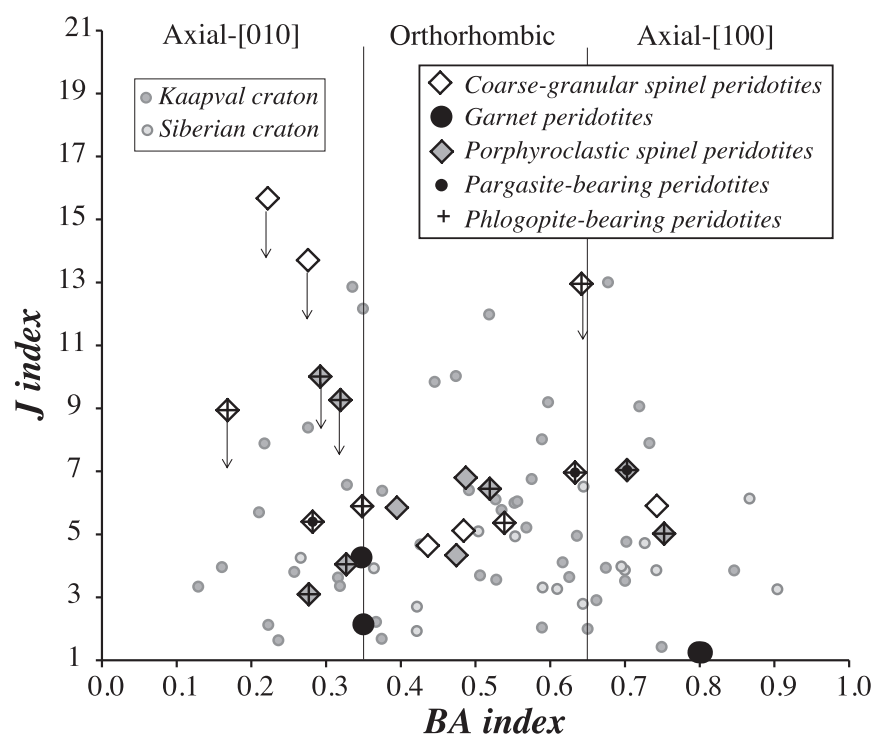

Fig. 10. Olivine CPO symmetry (BA index) vs. CPO strength (J index). Data for mantle xenoliths from the Kaapvaal (Baptiste et al., 2012) and Siberian cratons (Bascou et al., 2011) recalculated using MTEX with the same parameters as the present study are shown for comparison. Arrows indicate samples for which the J-index is probably overestimated due to the coarse olivine grain size and small size of the xenoliths.

and porphyroclastic peridotites display similar variability in intensity and symmetry of the olivine CPO (Fig. 10), consistent with previous observations in mantle xenoliths from the Kaapval (Baptiste et al., 2012) and Siberian cratons (Bascou et al., 2011). Most spinel-peridotites do not show any clear SPO. Their olivine CPO cannot therefore be directly related to a structural reference frame. Nevertheless, the coarse-granular peridotite Lm1-20a, which displays a strong SPO marking the foliation and lineation (Fig. 5a,b), has correlated olivine CPO and SPO: the maximum concentrations of [010] and [100] axes are oriented perpendicular and parallel to the grains elongation, respectively (Fig. 11).

In several spinel peridotites, as in the garnet peridotites, the number of clino- and orthopyroxene crystals in the thin sections was low and, thus, the resulting CPO are not statistically representative (Fig. 11). When enough grains could be measured, the CPO of ortho- and clinopyroxene are generally weaker than that of olivine. Most coarsegranular spinel peridotites have orthopyroxene CPO correlated with the olivine CPO: the $[001]_{\mathrm{opx}}$ and [100] $]_{\mathrm{opx}}$ maxima tend to align with the $[100]_{\mathrm{ol}}$ and $[010]_{\mathrm{ol}}$ maxima, respectively (Fig. 11). The exceptions are the coarse-granular spinel peridotites In1-20a and In1-34, which have almost random orthopyroxene $\mathrm{CPO}$, and In1-3, which displays [001] maxima for clino- and orthopyroxene subparallel to the [001] maximum. However, in contrast to the garnet peridotites, the spinel peridotite In1-3 displays an olivine CPO characterized by a maximum concentration of [100] significantly stronger than the [001] one. In the porphyroclastic spinel peridotites, the correlation between olivine and orthopyroxene CPO is weaker (Fig. 11). Half of the porphyroclastic spinel peridotites show partial correlation between the orthopyroxene and olivine CPOs, whereas the other half has orthopyroxene CPO uncorrelated with the olivine CPO.

In $>50 \%$ of the spinel peridotites, the clinopyroxene $\mathrm{CPO}$ is similar to the orthopyroxene CPO. The clusters of [100], [010] and [001] of clinopyroxene duplicate the clusters of the same axes of orthopyroxene (Fig. 11). This similarity is strongest in samples In1-1, In1-20b and In1-24a, where most or all clinopyroxenes occur as small crystals rimming the orthopyroxenes (Fig. 5g, 6). EBSD crystallographic orientation maps show that all clinopyroxene grains rimming a coarse orthopyroxene have orientations similar to that of the orthopyroxene, implying topotaxial replacement of orthopyroxene by clinopyroxene. In the remaining spinel peridotites, which display coarser clinopyroxenes with often an interstitial habitus, the clinopyroxene CPO is very weak, nearly random, and does not show clear correlation with the $\mathrm{CPO}$ of olivine or orthopyroxene.

\section{Thermobarometry}

Due to the secondary nature of most clinopyroxenes, indicated by their interstitial habitus (Figs. 3 and 5) and chemical disequilibrium relative to the bulk-rock (Fig. 8e), two-pyroxene thermometers provide spurious estimates for many samples. We focus therefore on the equilibrium temperatures calculated using the $\mathrm{Ca}$ in orthopyroxene thermometer (Brey et al., 1990, revised by Nimis and Grütter, 2010). The garnet peridotites yield equilibrium temperatures around $1230-1240{ }^{\circ} \mathrm{C}$ (Table 1). Their equilibrium pressures, estimated based on the garnet-orthopyroxene barometer (Nickel and Green, 1985), range between 5.2 and 5.4 GPa (Table 1). These values are consistent with previous estimates for garnet peridotites from the Canastra-1 and Três Ranchos diamond-bearing kimberlites (Costa, 2008). Although there is a large dispersion, the ensemble of the pressure-temperature data for APIP garnet peridotites is coherent with a typical cratonic steady-state geotherm built using surface and reduced heat flows of 40 and $20 \mathrm{~mW} / \mathrm{m}^{2}$, respectively, which intercepts the $1350{ }^{\circ} \mathrm{C}$ adiabat at $\sim 200 \mathrm{~km}$ depth (Fig. 12).

Equilibrium temperatures for the spinel-peridotites range between $620{ }^{\circ} \mathrm{C}$ and $1057{ }^{\circ} \mathrm{C}$ (Table 1). Coarse-granular peridotites display on average lower equilibrium temperatures than coarse-porphyroclastic peridotites, although there is some overlap between the two groups (Fig. 12). Although there is no reliable barometer for spinel peridotites, maximum equilibrium depths for these rocks may be estimated based on the absence of garnet in their mineralogy and on their $\mathrm{Cr} /(\mathrm{Cr}+\mathrm{Al})$ contents, which control the spinel to garnet transition (Klemme, 2004; Ziberna et al., 2013). The temperature and pressure estimates for the spinel peridotites cannot be reconciled with a cratonic steady-state geotherm, in contrast to that of the garnet peridotites xenoliths (Fig. 12 and Table 1). However, the data for all samples, except the hottest one (coarse-porphyroclastic spinel lherzolite In1-1), are coherent with a geotherm characterized by surface and reduced heat flows of 50 and $30 \mathrm{~mW} / \mathrm{m}^{2}$, respectively (Fig. 12). This warmer geotherm predicts a $132 \mathrm{~km}$ thick lithosphere.

The porphyroclastic spinel lherzolite In1-1, which does not fit to this geotherm, shows an extreme variation in Ca content (0.26-1.5 vol\% $\mathrm{CaO}$ ) in orthopyroxene and is characterized by fine-grained clinopyroxene and spinel aggregates rimming the orthopyroxene crystals (Fig. 6), consistent with Ca enrichment towards the rims. If the analyses are separated in two groups with a limit at $1 \mathrm{vol} \% \mathrm{CaO}$, we obtain temperatures of $883^{\circ} \mathrm{C}$ and $1173{ }^{\circ} \mathrm{C}$. Thus, the high equilibrium temperature obtained for this sample is likely associated with reactive melt transport and did not represent a steady-state geotherm.

\section{Seismic properties}

We computed the seismic properties of all spinel peridotites at different depths $(45,75,100,125,150$, and $175 \mathrm{~km})$ along both a cold cratonic geotherm (surface and reduced heat flows of 40 and $20 \mathrm{~mW} /$ $\mathrm{m}^{2}$, respectively) and a warmer geotherm (surface and reduced heat flows of 50 and $30 \mathrm{~mW} / \mathrm{m}^{2}$, respectively). The cold geotherm is consistent with the garnet peridotites equilibrium conditions, whereas the warmer one fits the equilibrium conditions of the spinel peridotites (Fig. 12). Seismic properties for the garnet peridotites were calculated at their equilibrium pressure and temperature. The density, elastic constants, and seismic properties for all individual samples are presented in Supplementary Material Table S3. 

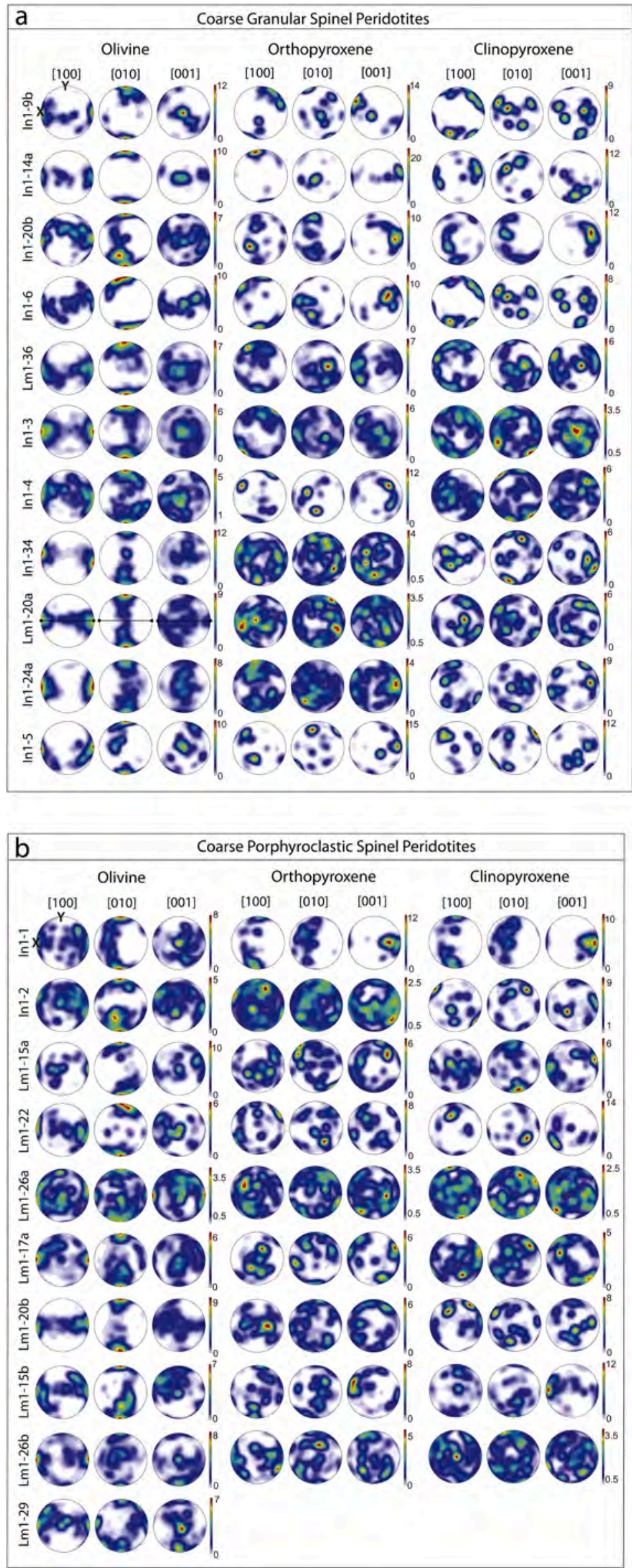

Fig. 11. Crystal preferred orientations (CPO) of olivine, orthopyroxene, and clinopyroxene for the spinel peridotites: (a) coarse-granular and (b) coarse-porphyroclastic. Lower hemisphere stereographic projections. To allow easy comparison among different samples, all CPO were rotated into a common orientation, with the eigenvector of the olivine [010]-axis distribution in the N-S direction of the pole fig. $(\mathrm{Y})$ and that of the [100]-axis as close as possible to the $\mathrm{E}-\mathrm{W}$ direction (X). The line and dot in the olivine pole figure of sample Lm1-20a represent the foliation and lineation defined by the olivine shape preferred orientation. 


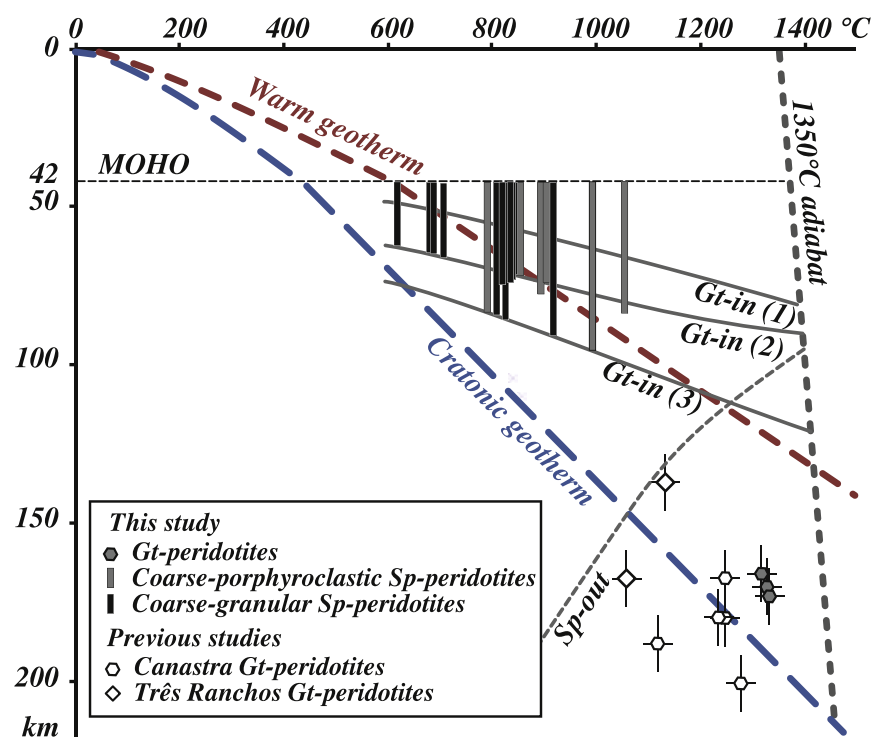

Fig. 12. P-T plot comparing the equilibration conditions estimated for the studied mantle peridotites to a typical cratonic geotherm (surface and reduced heat flows of 40 and $20 \mathrm{~mW} / \mathrm{m}^{2}$, respectively) and a warmer geotherm (surface and reduced heat flows of 50 and $30 \mathrm{~mW} / \mathrm{m}^{2}$, respectively). As no barometers are available for spinel peridotites equilibrium pressure ranges are presented as bars, based on the absence of plagioclase and of garnet in the studied peridotites, considering their $\mathrm{Cr}$ and $\mathrm{Al}$ contents (Supplementary Information Table S1) and the effect of $\mathrm{Cr}$ on the spinel-garnet phase transition. Phase transitions after Ziberna et al. (2013). Garnet-in curves are displayed for a fertile lherzolite = Gt-in(1), a cratonic clinopyroxene-bearing peridotite (LSK261) representative of refractory subcratonic mantle that underwent low degrees of refertilization $=\mathrm{Gt}$-in(2), and a refractory peridotite $=\mathrm{Gt}$-in(3). The spinel-out curve is based on the composition of the cratonic peridotite LSK261. Moho depth is based on receiver function data (Assumpção et al., 2017).

\subsection{Seismic anisotropy}

Seismic anisotropy varies weakly with temperature and pressure. Fig. 13 presents the maximum anisotropy for P-, S-, and surface waves calculated using the warm geotherm at $75 \mathrm{~km}$ depth for all spinel peridotites and at $175 \mathrm{~km}$ depth for the garnet peridotites. The maximum propagation anisotropy of $\mathrm{P}$ - and the maximum polarization anisotropy of S-waves are positively correlated, with the maximum P-wave propagation anisotropy usually higher than the S-wave polarization one (Fig. 13a). The maximum propagation anisotropy of the slow $S_{2}$-wave and $\xi$, which correspond to the azimuthal anisotropy of Rayleigh waves and the radial anisotropy of surface waves $\left(\xi=\left(\frac{V_{S H}}{V_{S V}}\right)^{2}\right.$ ), respectively, if the olivine [100] and [010] maxima are horizontal and vertical, respectively, are also positively correlated (Fig. 12b). The variation in intensity of the seismic anisotropy among the studied samples results essentially from variations in the olivine modal content and CPO intensity and, to a lesser extent, in the olivine CPO symmetry (Figs. 2 and 9). Higher olivine modal contents and CPO intensities are associated with stronger anisotropy. The very weak olivine $\mathrm{CPO}$ of most garnet peridotites results in very weak anisotropy for all seismic waves (Fig. 13). There is no relation between microstructure and intensity of seismic anisotropy in the spinel-peridotites, in consistency with the lack of correlation between microstructure and olivine CPO intensity or symmetry (Fig. 9).

Since seismic waves average properties over large volumes (tens of $\mathrm{km}$ wide), we calculated mean seismic properties for the shallow mantle lithosphere by averaging the elastic properties of all spinel peridotites of the Limeira-1 and Indaiá-1 pipes. This averaging represents the maximum anisotropy that may be associated with the studied xenoliths, since it considers a coherent orientation of the flow direction and plane for all samples. Average seismic properties of the spinel peridotites at different depths for the two geotherms are presented in Table 2. The average seismic properties of the spinel peridotites at $75 \mathrm{~km}$ depth estimated using the cratonic geotherm are presented in Fig. 14 (top). For the deep lithospheric mantle, the average sample calculated based on the elastic properties of all garnet peridotites has a very weak anisotropy, due to the strong dispersion of the olivine $\mathrm{CPO}$ resulting from recrystallization. Because this recrystallization likely is a late phenomenon associated with the kimberlite magmatism (cf. discussion section), we choose to present in Fig. 14 (bottom) the seismic properties of the least recrystallized garnet peridotite $\mathrm{C} 100$ as representative of the deep lithospheric mantle.

Most studied xenoliths do not display a clear shape preferred orientation, which would define the relation between the olivine CPO and the past flow direction and plane. Thus, in the following, the seismic properties are described relative to the olivine CPO reference frame (cf.
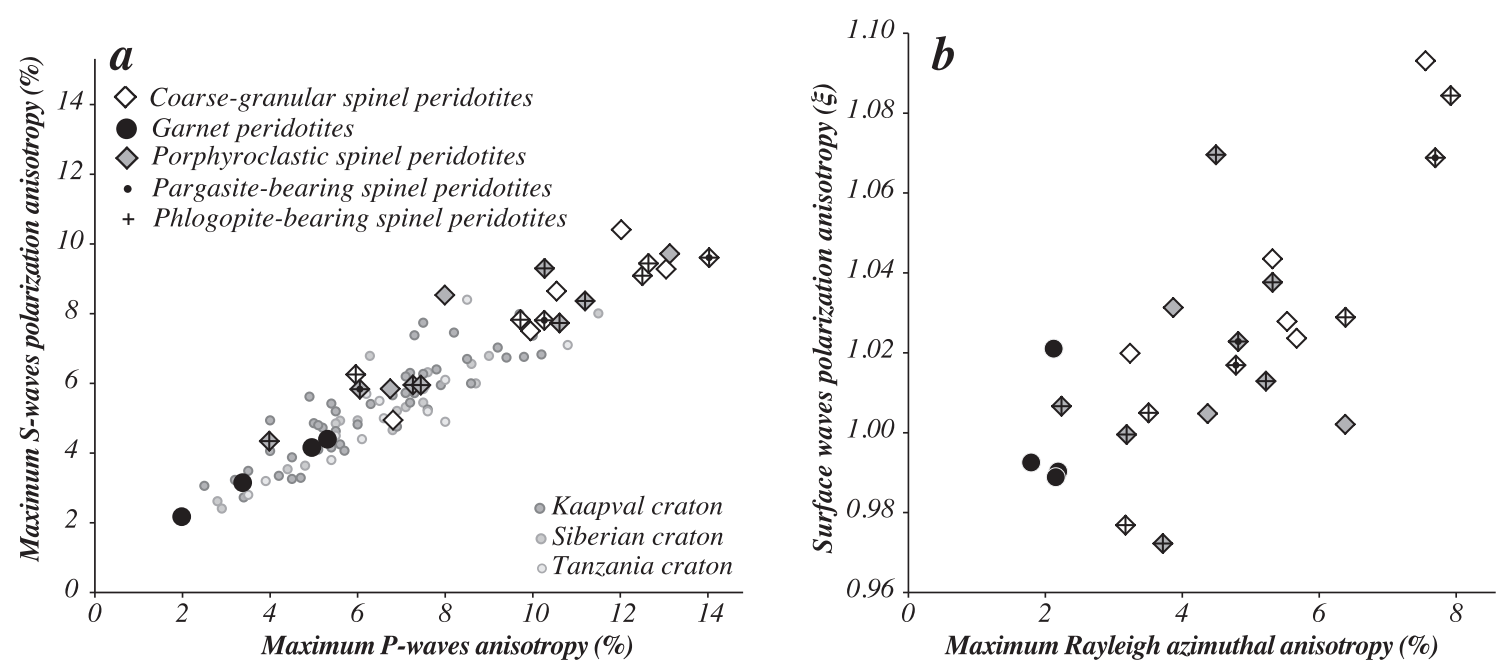

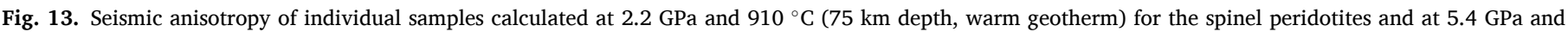

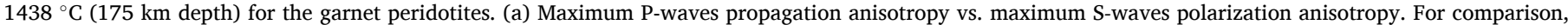

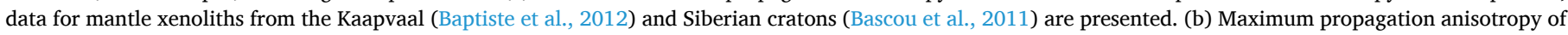

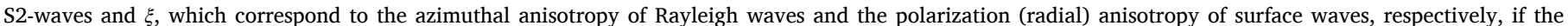
maximum of $[100]_{\mathrm{ol}}$ is horizontal and that of $[010]_{\mathrm{ol}}$ is vertical. 


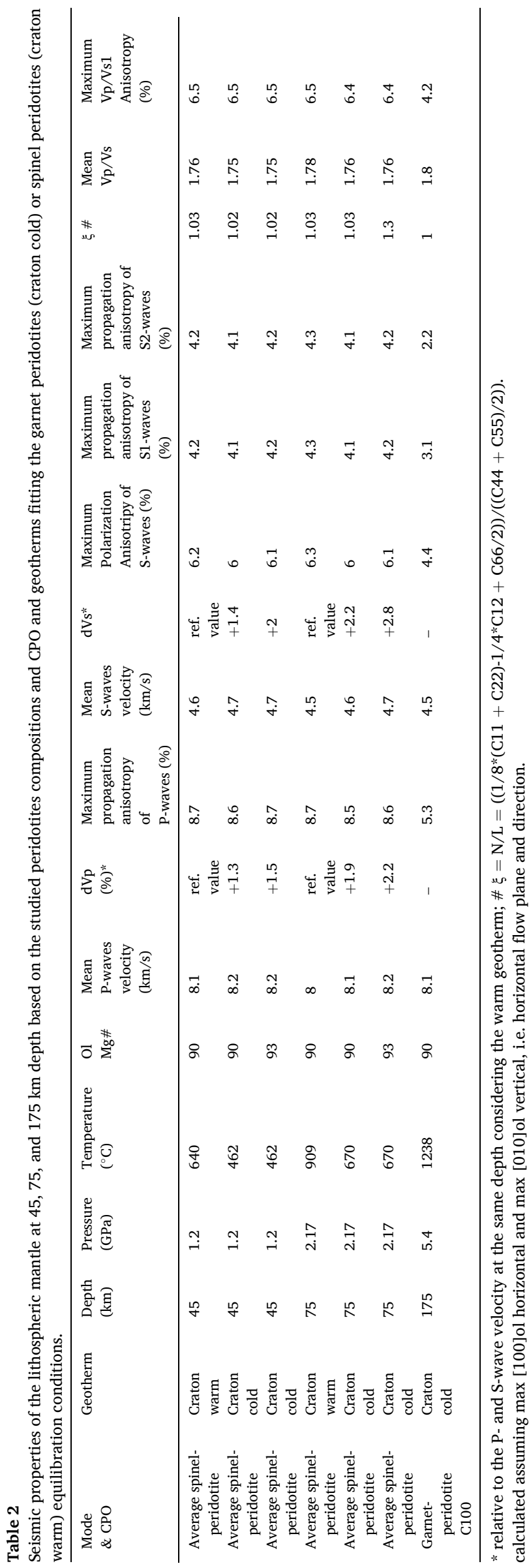

Fig. 14). The mean spinel-bearing peridotite is more anisotropic than the garnet-bearing peridotite, but the seismic anisotropy patterns are similar. The fastest $\mathrm{P}$-wave propagation and the $\mathrm{S}$-wave fast polarization are parallel to the $[100]_{\mathrm{ol}}$ maximum and the slowest $\mathrm{P}$-wave velocities to the $[010]_{\mathrm{ol}}$ maximum. High polarization anisotropy should be observed for S-waves propagating at high angle to both the $[100]_{\mathrm{ol}}$ and the $[010]_{\mathrm{ol}}$ maxima, whereas apparent isotropy should be observed for waves propagating within $\pm 30^{\circ}$ to the $[100]_{\mathrm{ol}}$ maximum and $\pm 60^{\circ}$ to the $[010]_{\mathrm{ol}}$ maximum. $\mathrm{Vp} / \mathrm{Vs}$ ratios are also anisotropic. The lowest values correspond to propagation directions parallel to the $[010]_{\mathrm{ol}}$ maximum and the highest for propagation directions parallel to the $[100]_{\mathrm{ol}}$ maximum.

For relating fast- and slow- S-wave velocity $\left(\mathrm{Vs}_{1}\right.$ and $\left.\mathrm{Vs}_{2}\right)$ patterns to surface wave data, one needs to make a hypothesis on the geographical orientation of olivine CPO. If the [100] maximum is horizontal, Love waves will correspond to $S_{1}$ in Fig. 14. They will show moderate to weak azimuthal anisotropy $(\leq 2 \%)$ with a $90^{\circ}$ periodicity and fastest propagation at $45^{\circ}$ of the $[100]_{\mathrm{ol}}$ maximum. Rayleigh waves will correspond to $S_{2}$ in Fig. 14. The Rayleigh waves azimuthal anisotropy will be moderate (up to $4 \%$ ) in the shallow lithospheric mantle and weak in the deep mantle lithosphere (up to $2 \%$ ), with a $180^{\circ}$ periodicity and fastest propagation parallel to the flow direction. The surface waves' radial anisotropy will vary as a function of the propagation azimuth, displaying an azimuthally averaged $\xi$ of 1.03 (Table 2).

\subsection{Effects of heating and compositional variations on seismic velocities}

Analysis of the mineral compositions (Figs. 7 and 8) and the equilibrium pressure and temperature conditions (Fig. 12) supports that the studied peridotites have been variably enriched in Fe and heated relative to the original cratonic conditions. The possible effect of these processes on the seismic velocities was estimated by comparing seismic velocity profiles calculated for an isotropic refractory peridotite using the cratonic and the warmer geotherms (Fig. 15). For the cratonic geotherm, we also considered the effect of varying the Fe content in olivine by comparing seismic velocities calculated for olivine with $\mathrm{Mg} \# 93$ (which is a typical cratonic composition) and $\mathrm{Mg} \# 90$ (the average value in the spinel peridotites).

For the cratonic geotherm, which is associated with a $\sim 200 \mathrm{~km}$ thick plate, $\mathrm{P}$ - and S-wave velocities decrease and $\mathrm{Vp} / \mathrm{Vs}$ ratio increases continuously from the Moho to $175 \mathrm{~km}$ depth (Fig. 15). For the warmer geotherm, a minimum in both P- and S-wave velocities at $\sim 125 \mathrm{~km}$ depth marks the lithosphere-asthenosphere boundary (Fig. 15a,b). This minimum results from a change between temperature-controlled seismic velocities in the lithosphere to pressure-controlled ones in the asthenosphere, where an adiabatic temperature gradient prevails. The maximum contrast in seismic velocity between the two geotherms: $3 \%$ for mean (isotropic) P-waves and 3.5\% for S-waves, is observed at this depth. The velocity contrast associated with two geotherms decreases towards the Moho (Fig. 15a,b). It is of 1.2\% for mean P-waves and 1.4\% $\mathrm{S}$-waves velocities at $45 \mathrm{~km}$ depth. Vp-Vs1 ratios are lower for the colder geotherm at all depths, but the difference is small (Fig. 15c).

Varying the Fe-content of olivine enhances the contrast in seismic velocities. Compared to a cold and Fe-depleted craton, P-waves in a warm lithospheric mantle with a standard olivine composition ( $\mathrm{Mg} \# 90$ ) are reduced by $1.5 \%$ and S-waves by $2 \%$ at $45 \mathrm{~km}$ and by $3.2 \%$ and $4.1 \%$, respectively, at $125 \mathrm{~km}$ depth. $\mathrm{Vp} / \mathrm{Vs}$ ratios are increased. However, for both $\mathrm{P}$-wave velocity and $\mathrm{Vp} / \mathrm{Vs}$ ratio, the variation due to the modeled change in temperature and/or composition is at all depths significantly lower than the range of variability due to anisotropy at constant temperature and composition. The variation in S-wave velocities due to a change in the geotherm (with or without a change in $\mathrm{Fe}$ content of olivine) is equivalent to the one that could be produced by anisotropy alone in most of the lithospheric mantle.

The seismic profiles in Fig. 15 were calculated for a garnet-free, refractory composition, which corresponds to the mean composition of the 


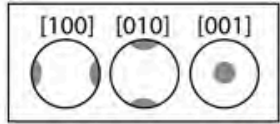

Average

spinel-peridotite

@ 75 km depth

$2.17 \mathrm{GPa}, 670^{\circ} \mathrm{C}$

\section{Cratonic geotherm}

\section{Garnet-peridotite C100 \\ @ $175 \mathrm{~km}$ depth \\ $5.4 \mathrm{GPa}, 1238^{\circ} \mathrm{C}$}

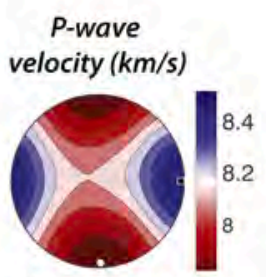

Max Anis = 8.5\%

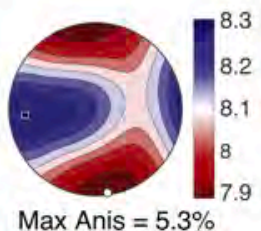

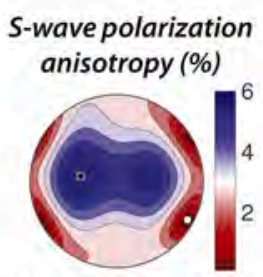

Max Pol Anis $=6.0 \%$

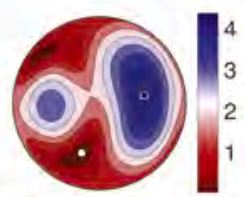

Max Pol Anis $=4.4 \%$

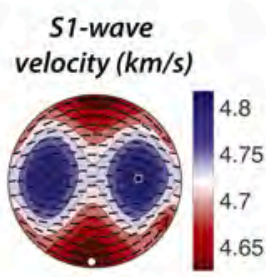

Max Anis $=4.1 \%$

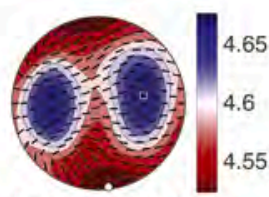

Max Anis $=3.3 \%$
S2-wave

velocity $(\mathrm{km} / \mathrm{s})$

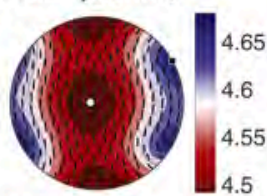

Max Anis = 4.1\%

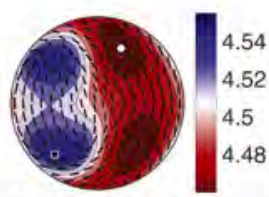

Max Anis $=2.1 \%$
VPNS1 ratio

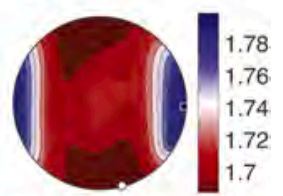

Max Anis $=6.4 \%$

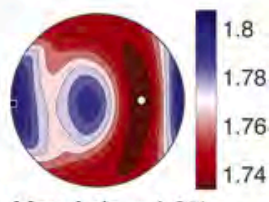

Max Anis $=4.2 \%$

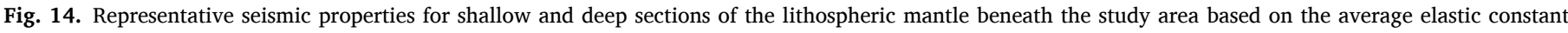

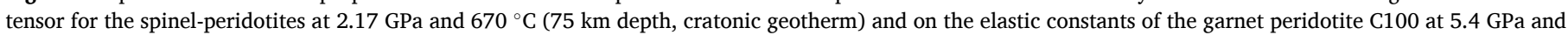

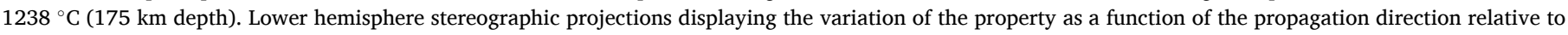

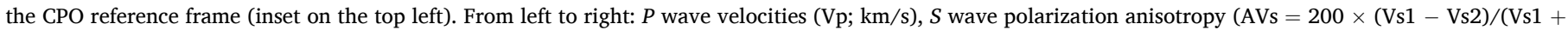

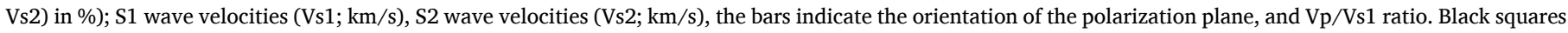

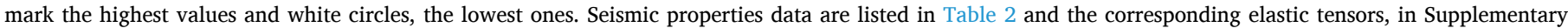
Material Table S4.

spinel peridotites. In more fertile ( $\mathrm{Al}$ and Ca-rich) peridotites, occurrence of garnet results in higher $\mathrm{P}$ - and S-wave velocities and lower $\mathrm{Vp}$ / Vs below 75-90 km depth, as documented by the difference between the seismic velocities calculated at $175 \mathrm{~km}$ for the cratonic geotherm for the garnet-peridotite $\mathrm{C} 100$ (6\% garnet), and a refractory peridotite (no

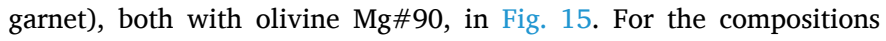
considered, the seismic velocities of a refractory peridotite (no garnet

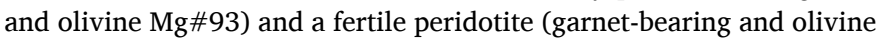
$\mathrm{Mg \# 90)} \mathrm{are} \mathrm{similar.} \mathrm{However,} \mathrm{the} \mathrm{density} \mathrm{of} \mathrm{the} \mathrm{refractory} \mathrm{peridotite} \mathrm{is}$ significantly lower $\left(3.38 \mathrm{~kg} \cdot \mathrm{m}^{-3}\right.$ relative to $3.54 \mathrm{~kg} \cdot \mathrm{m}^{-3}$; Supplementary Material Tables $3 \& 4$ ). The gravimetric signatures of the two lithologies will therefore differ.

\section{Discussion}

10.1. Composition, microstructures, and thermal evolution of the lithospheric mantle

The petrostructural analysis of mantle xenoliths from three kimberlitic pipes intruding the external domains of the Neoproterozoic Brasilia belt highlights characteristics similar to observations in cratonic roots worldwide. However, the present study also brings to light evidence for modification of this cratonic root by reactive melt percolation, with minor associated deformation. These observations are described and discussed in the following.
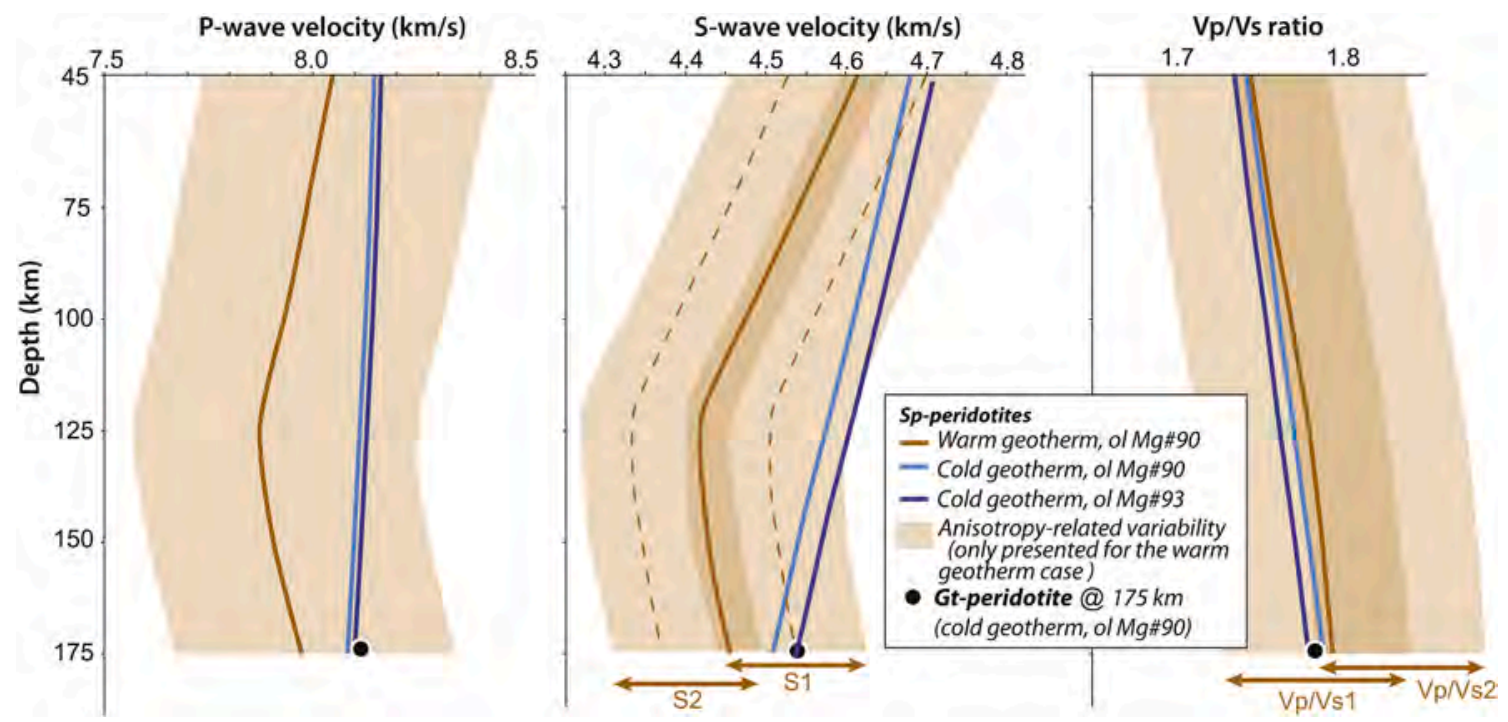

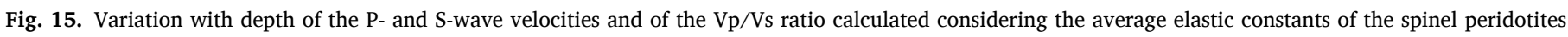

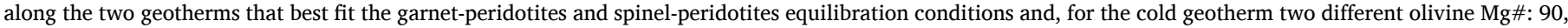

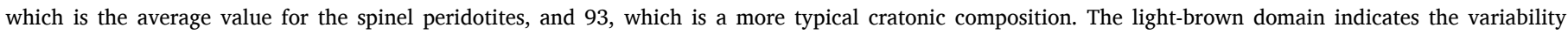

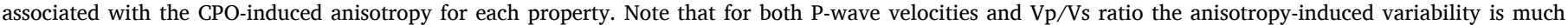

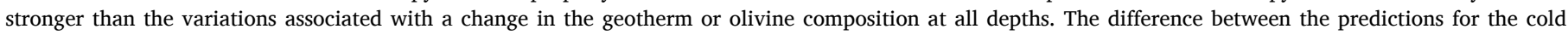

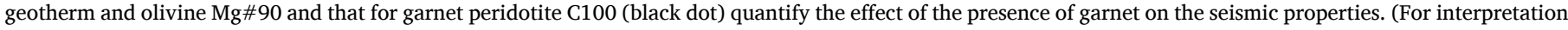
of the references to colour in this figure legend, the reader is referred to the web version of this article.) 
The xenolith sampling from cratonic roots worldwide shows a predominance of refractory peridotites with coarse-granular textures in most of the lithospheric mantle, but more fertile peridotites with fineporphyroclastic microstructures (often described as 'mylonitic, mosaic, or fluidal') are common among the peridotites equilibrated at the highest temperatures and pressures (Boullier and Nicolas, 1975; Boyd and Nixon, 1975; Harte, 1977; Griffin et al., 1999; Kopylova and Caro, 2004; Vauchez et al., 2005; Bascou et al., 2011; Baptiste et al., 2012). This variation with depth of composition and microstructure is also observed among the presently studied mantle xenoliths.

The garnet-peridotites, which sample the deeper part of the lithospheric mantle (Fig. 12), have more fertile compositions (Figs. 2, 7, 8, Table 1). Similarly to the 'mylonitic' microstructures of deep kimberliteborne peridotites from other cratons, the fine-porphyroclastic microstructures and high equilibration temperatures of the Canastra-1 garnetperidotite xenoliths imply high-stress deformation shortly before their extraction by the kimberlitic magmas. The preservation of domains in which recrystallized olivine grains display a similar CPO, coherent with the orientation of remaining portions of their parent grain, but markedly different than the CPO from neighboring domains (Fig. 9) indicates nevertheless low finite strains, despite the almost total recrystallization of the olivine. We follow therefore previous studies (Green and Gueguen, 1974; Goetze, 1975; Vauchez et al., 2005; Skemer and Karato, 2008; Baptiste et al., 2012; Tommasi and Ishikawa, 2014; Liu et al., 2019) and propose that the recrystallization producing the fine-grained porphyroclastic microstructures is related to the formation of the dykes allowing for the fast transport of the kimberlitic magmas from the base of the craton to the surface. The main arguments justifying this interpretation are: (1) at the high equilibration temperatures that characterize these xenoliths $\left(\geq 1200{ }^{\circ} \mathrm{C}\right)$ grain growth is fast and small recrystallized grain sizes cannot be preserved for long times, implying that the deformation shortly predated extraction, and (2) strain rates calculated based on olivine flow laws using the equilibrium temperatures and stresses estimated based on the recrystallized grain sizes are too fast $\left(>>10^{-10} \mathrm{~s}^{-1}\right.$ ) to represent the deformation at the base of the craton associated with a velocity gradient related to the convective mantle. This microstructure records therefore a high stress, but low strain event, leading to 'fragmentation' of the rock without large displacements. The high temperatures $\left(>1200{ }^{\circ} \mathrm{C}\right.$, Fig. 12) allowed for partial re-equilibration of the microstructure, producing the polygonal arrangement of olivine neoblasts in the matrix (Figs. 3a,b).

Half of the studied spinel-peridotites have coarse-granular microstructures and dominantly refractory compositions. Their coarse grain sizes, straight olivine grain boundaries, and low intragranular misorientations (Figs. 4,5), together with well-developed CPOs (Figs. 10, 11) point to deformation followed by effective annealing, which produced almost full microstructural re-equilibration. Effective annealing despite the rather low equilibration temperatures $\left(<900{ }^{\circ} \mathrm{C}\right.$; Fig. 12) implies a long quiescence interval since the last deformation episode. The cusp-like terminations of orthopyroxenes in the coarse-granular peridotites (Fig. 5a,b) record post-kinematic reactive melt migration. The gently curved boundaries of these orthopyroxenes suggest, however, that this reactive melt percolation is ancient. Additional evidence for interaction with percolating melts or fluids encompasses occurrence of interstitial phlogopite or pargasite (Table 1) and Ti-enrichment in pyroxenes (Fig. 8f) in some samples. However, the timing of this metasomatism cannot be determined.

In contrast, the other half of the presently studied spinel-peridotites display coarse-porphyroclastic microstructures, which are rare in spinel peridotites from cratonic environments (e.g., Boullier and Nicolas, 1975; Harte, 1977; Vauchez et al., 2005; Bascou et al., 2011; Baptiste et al., 2012). These samples show a peculiar microstructure, in which roughly polygonal coarse olivine grains show a short length-scale sinuosity of their boundaries, rather high intragranular misorientations, and are often rimmed by fine-grained neoblasts (Figs. 4, 5). We interpret this microstructure as resulting from the modification of the original coarse- granular microstructure by a process that shortly predated the extraction of the xenoliths by the kimberlitic magmatism, since annealing, which is favored by long residence times in the lithospheric mantle at temperatures $>900{ }^{\circ} \mathrm{C}$, would have decreased the intragranular misorientation, smoothed the sinuosity of the olivine grain boundaries, and increased the recrystallized grain sizes. The increase in intragranular misorientation implies a higher density of stored dislocations and, hence, an increase in deviatoric stress. The olivine recrystallized grain sizes $<100 \mu \mathrm{m}$ imply stresses $>50 \mathrm{MPa}$ using the calibration of Van der Wal et al. (1993). Thus, deformation at rather high stress was involved in the development of the porphyroclastic microstructure in the spinel peridotites. However, finite strains must have remained low, since the porphyroclasts preserved roughly equiaxed shapes and display no shape preferred orientation.

The porphyroclastic spinel peridotites display extensive petrographic and geochemical evidence for reactive melt percolation. This evidence encompasses: (1) the very irregular grain boundaries of orthopyroxene, which show short-wavelength embayments filled by olivine (Fig. 5e,f,g, h), (2) pyroxenes and spinels with interstitial habitus forming anastomosed networks or patches in the more fertile coarse-porphyroclastic peridotites (Fig. 5e), (3) the very fine-grained aggregates of clinopyroxene and minor spinel that rim, of fill fractures in, orthopyroxene crystals in the more refractory coarse-porphyroclastic peridotites (Fig. 6), and (4) the common occurrence of modal phlogopite, which is usually associated with Fe-enrichment in olivine and pyroxenes, Caenrichment of olivine, and in some samples Ti-enrichment of pyroxenes (Fig. 8). Based on the association of microstructural features pointing to high stress, but low strain, evidence for reactive melt percolation, and lack of annealing, we interpret the coarseporphyroclastic peridotites as recording microstructural and compositional changes related to reactive melt transport through the lithospheric mantle, shortly before and during the APIP magmatism.

Another major characteristic of cratonic roots is the cold geotherm (e.g., Boyd and Nixon, 1975; Harte, 1977). Equilibrium temperatures and pressures substantiate that the fine-porphyroclastic garnet peridotites are equilibrated on a typical cratonic geotherm (Fig. 12). However, the equilibration conditions of all spinel peridotites imply a warmer geotherm or local transient heating in the lithospheric mantle. Among the spinel peridotites, the coarse-porphyroclastic ones yield on average higher equilibrium temperatures than the coarse-granular ones (Fig. 12). This is consistent with the more extensive evidence of microstructural and compositional changes in the coarseporphyroclastic peridotites (Figs. 5 and 8).

Garnet- and spinel-peridotites are derived from kimberlitic pipes with different ages: $\sim 120$ Ma for Canastra-1 (Pereira and Fuck, 2005) and 80-91 Ma for Indaiá-1 and Limeira-1, respectively (Guarino et al., 2013). They probably sample not only different depths and locations of the cratonic mantle, but also different stages of its evolution in response to the APIP magmatism: the xenoliths from Canastra- 1 sampling the state of the mantle at the beginning of the APIP magmatism and those from Limeira-1 and Indaiá-1 at a later stage. The better fit of the equilibrium temperatures of the Limeira- 1 and Indaiá-1 xenoliths by a warmer geotherm than that adjusting the Canastra-1 garnet-peridotite data (Fig. 11) suggests therefore moderate heating of the lithospheric mantle between the extraction of the garnet peridotites by the Canastra1 kimberlite at $120 \mathrm{Ma}$ and of the spinel peridotites by the Limeira- 1 and Indaiá-1 kimberlites at 80-91 Ma. This is consistent with the presence of diamond in the Canastra-1 kimberlite and its absence in the two other pipes. Heating of the lithospheric mantle during the APIP magmatism had previously been suggested based on comparison of geothermometry in clinopyroxenes from APIP kimberlites and kamafugites, which hinted at heating of the lithospheric mantle by $\sim 250{ }^{\circ} \mathrm{C}$ between the two magmatic events, that is, between 89 and $85 \mathrm{Ma}$ (Read et al., 2004). The present data implies heating started before $90 \mathrm{Ma}$.

Based on these observations, we conclude that the studied peridotites sample a cratonic mantle, which was modified by reactive melt 
percolation during the formation of the APIP. Our data support therefore the westward continuation of the São Francisco craton beneath the eastern Brasilia belt proposed based on geophysical data (Assumpção et al., 2004; Pereira and Fuck, 2005; Rocha et al., 2011; Assumpção et al., 2017; Rocha et al., 2019). The present observations also support that reactive melt percolation during the formation of the APIP resulted in significant modification of the composition and moderate heating, thinning the lithospheric mantle to $\leq 130 \mathrm{~km}$ beneath the igneous province. This interpretation is also supported by previous thermobarometric and geochemical data for mantle xenoliths brought to the surface by the APIP magmatism (Carvalho and Leonardos, 1997; Read et al., 2004; Carlson et al., 2007; Costa, 2008). The petrophysical data on the xenoliths represent a step forward by allowing quantitative estimations of the effect of these changes on the seismic signature of the lithospheric mantle beneath the APIP.

\subsection{Crystal preferred orientations and seismic anisotropy}

Olivine CPO in coarse-granular and coarse-porphyroclastic spinel peridotites are similar (Figs. 9,10); this is consistent with the assumption that the finite strain involved in the change from coarse-granular to coarse-porphyroclastic microstructure was weak. By consequence, this change in microstructure did not significantly modify the seismic anisotropy signature of the cratonic root (Fig. 13). In contrast, the almost complete recrystallization of olivine in the garnet peridotites resulted in significant dispersion of the olivine $\mathrm{CPO}$ and reduction of the seismic anisotropy (Figs. 9, 13). However, if the fine-porphyroclastic microstructure of these samples results from the initial stages of the kimberlitic magmatism, as proposed in the previous section, the occurrence of such microstructures and the associated reduction in seismic anisotropy may be restricted to small volumes of the base of the lithospheric mantle beneath the craton, which are over-represented in the sampling by the Canastra- 1 kimberlite.

For the spinel peridotites, the clear olivine CPO with dominantly orthorhombic patterns characterized by [100] and [010] maxima stronger than the [001] one is best interpreted as formed through deformation by dislocation creep with dominant activation of the [100] (010) slip system in response to pure or simple shear (Tommasi et al., 1999; Tommasi et al., 2000). This interpretation is corroborated by the relation between olivine CPO and SPO in peridotite Lm1-20 (Fig. 5a,e), which is the sole sample in the suite displaying a clear lineation and foliation. Further constraints on the relation between the olivine CPO and the macroscopic deformation may be derived, nevertheless, from the joint analysis of the olivine and pyroxene CPO. The parallelism between the $[100]_{\mathrm{ol}}$ and $[001]_{\mathrm{opx}}$ maxima and of $[010]_{\mathrm{ol}}$ and $[100]_{\mathrm{opx}}$ maxima observed in most coarse-granular peridotites and part of the coarse-porphyroclastic peridotites, points to coherent deformation of the two phases. This relation between olivine and orthopyroxene CPO corroborates dominant activation of [100] glide in olivine, because orthopyroxene deforms essentially by glide of dislocations along the [001] direction (Raleigh and Paterson, 1965; Green and Radcliffe, 1972; Ross and Nielsen, 1978; Frets et al., 2012). The uncorrelated olivine and pyroxene CPO for the remainder coarse-porphyroclastic peridotites is interpreted as recording post-kinematic crystallization of pyroxenes. This interpretation is supported by the interstitial shapes and chemical evidence for metasomatism in these peridotites (Figs. 5 and 7). The olivine CPO measured in the spinel peridotites corresponds therefore to that most commonly observed in mantle peridotites (cf. reviews in Ben Ismail and Mainprice, 1998; Tommasi and Vauchez, 2015). It is consistent with deformation under moderate to high temperature, moderate pressure, dry conditions.

In contrast, the garnet peridotites have olivine CPO characterized by two weak orthogonal maxima of [100] and [001] or a stronger concentration of [001] than [100] and parallelism between the [001 $]_{\mathrm{ol}}$ and $[001]_{\text {opx }}$ maxima. Similar CPO have been described in deep xenoliths from other cratons, like the Tanzanian and Kapvaal in Africa (Vauchez et al., 2005; Baptiste et al., 2012), where they were ascribed to simultaneous activation of the [001] and [100] glide directions in olivine, due to the higher pressures prevailing at these depths or high stresses during deformation (e.g., Durham and Goetze, 1977; Couvy et al., 2004; Mainprice et al., 2005; Demouchy et al., 2013).

The olivine CPO measured in the APIP peridotites produce seismic anisotropy patterns in which the fast propagation of $\mathrm{P}$ - and $\mathrm{S}_{2}$-waves and polarization of fast split $\mathrm{S}$-waves mark the the past or present flow direction in the lithospheric and sublithospheric mantle, respectively (cf. reviews in Ben Ismail and Mainprice, 2000; Tommasi and Vauchez, 2015). CPO and seismic anisotropy intensities estimated for the shallow sections of the lithospheric mantle are similar to those calculated for mantle xenoliths from the Kaapvaal, Tanzanian, and Siberian cratonic roots (Figs. 10 and 13). If we consider that the CPO of the spinel peridotites were less modified by the kimberlitic magmatism than that of the garnet peridotites, the spinel peridotites' average seismic properties (Fig. 14) represent an estimate of the maximum anisotropy in the mantle lithosphere beneath the sampling sites, since this averaging supposes a coherent orientation of the past flow direction and plane within the volume sampled by the seismic waves. The sign and intensity of the seismic anisotropy sampled by different waves will depend on the orientation of the past flow direction and plane. We may try therefore to constrain this orientation by the analysis of multiple seismological datasets.

Regional anisotropic surface wave tomography models are not available for continental South America. Global anisotropic surface wave tomography models show, nevertheless, a variation between positive radial anisotropy values at $125 \mathrm{~km}$ depth $(\xi \sim 1.05)$ to slightly negative values $(\xi \sim 0.98)$ at 250 depth beneath the SE Brazil (French and Romanowicz, 2014; Chang et al., 2014). Faster Love than Rayleigh waves in the uppermost mantle are corroborated by a two-station inversion up to periods of 50s, which samples essentially depths $<100 \mathrm{~km}$, north of the study region (Assumpção et al., 2004). The two sets of observations point to dominant horizontal flow directions within the lithospheric mantle, but dominant vertical flow directions in the sublithospheric mantle. The polarization anisotropy for S-waves estimated for the APIP spinel xenoliths, considering a fossil horizontal flow plane is slightly lower $(\xi \sim 1.03)$ than the one obtained in the tomographic models (Table 2). Yet, this xenolith-based calculation considers homogeneous azimuthal sampling, which is never achieved in reality. Higher $\xi$ values will be observed, for instance, if directions oblique to the fossil flow direction are more frequently sampled (Fig. 14). Vertical fossil flow planes with horizontal flow directions would produce positive but significantly smaller $\xi$ values (Fig. 14), less consistent with the seismological observations.

Teleseismic S-wave splitting data in the southwestern SFC show a consistent orientation of the fast polarization directions (Fig. 1), which vary from ESE-WNW $\left(120-130^{\circ}\right)$ in the vicinity of the Canastra kimberlite to $\mathrm{E}-\mathrm{W}$ in the vicinity of the Limeira-1 and Indaiá-1 pipes (James and Assumpção, 1996; Heintz et al., 2003; Assumpção et al., 2006; Chagas de Melo et al., 2018). These fast-polarization directions clearly contrast with the NE-SW fast polarizations measured further southeast, which are clearly parallel to the Neoproterozoic transpressional shear zones in the Ribeira belt (Figs. 1 and 16). This lateral variation in the orientation of the fast polarization direction of teleseismic S-waves has been interpreted as recording deviation of an asthenospheric flow globally parallel to the South America absolute plate motion by the SFC craton root (Heintz et al., 2003; Assumpção et al., 2006; Melo and Assumpção, 2018). However, the present study shows that the lithospheric mantle of the craton is anisotropic. As teleseismic S-wave splitting integrates the anisotropy over its path, these observations should therefore record the combination of the seismic anisotropy produced by olivine CPO fossilized in the lithosphere and that resulting from present-day flow in the asthenosphere. These two signals will add up if the fast-polarizations in the two layers are parallel, but interfere destructively if they are not, leading to lower apparent 


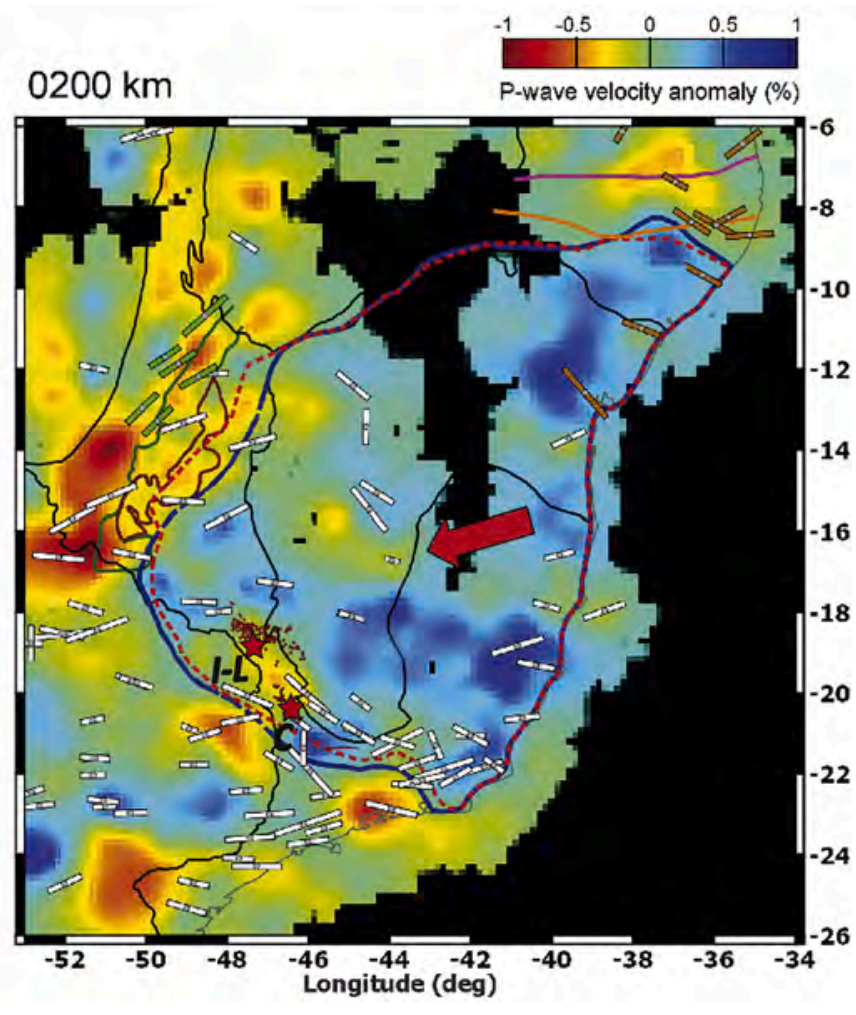

Fig. 16. Sampling sites for the studied mantle xenoliths and APIP magmatism relative to P-wave seismic tomography model of Rocha et al. (2019) at $200 \mathrm{~km}$ depth. The blue and dashed red lines indicate the extent of the craton deduced from seismic and gravity data, respectively (Rocha et al., 2019). White, green, and orange bars show teleseismic shear wave splitting data from Melo and Assumpção (2018), Prado et al. (2012), and Bastow et al. (2015). The red arrow indicates the South America absolute plate motion of model HS3-NUVEL1A. (For interpretation of the references to colour in this figure legend, the reader is referred to the web version of this article.)

delay times and fast polarizations that depend on the initial polarization of the incoming S-wave (Silver and Savage, 1994). Measured delay times vary from $0.6 \mathrm{~s}$ at station $\mathrm{BRCB}$ in the interior of the craton to $0.85-1.1 \mathrm{~s}$ in the stations on its southwestern border (Fig. 1).

The present study allows constraining the maximum possible contribution of the lithosphere to the measured shear wave splitting. Weak teleseismic S-wave splitting will be produced in the cratonic root if the past flow directions were vertical, whereas strong splitting will be produced if the past flow direction was horizontal and the flow plane vertical (Fig. 14). A fossil horizontal flow plane, which is the structure that best explains the polarization anisotropy detected in surface wave tomography models, would result in moderate polarization anisotropy $(<3 \%)$ for vertically propagating S-waves (Fig. 14). Considering that the cratonic lithospheric mantle is presently $100 \mathrm{~km}$ thick beneath the region sampled by the pipes, delay times of up to $0.6 \mathrm{~s}$ may be acquired within the cratonic root. Higher delay times would be produced within the thicker interior of the cratonic root. The lower delay times measured in the SFC interior relative to its southwestern border may therefore be explained by a higher obliquity between the lithospheric and asthenospheric anisotropy beneath the center of the SFC. They may also result from a weaker asthenospheric contribution beneath the thicker part of the craton, due to deformation concentrated in a thinner layer (Fouch et al., 2000), or to a change in olivine deformation with increasing pressure leading to less effective anisotropy production at depths $>250$ km (Mainprice et al., 2005).
10.3. Seismic velocities and variations in composition and thermal structure of the SFC lithospheric mantle

Regional body-wave seismic tomography models (Assumpção et al., 2017; Rocha et al., 2019) display higher than average velocities $(+1 \%$ in the most recent inversion of Rocha et al., 2019) over a broad area, which encompasses the southern part of the SFC and the foreland domains of the Neoproterozoic Araçuaí and Brasilia belts. However, beneath the APIP, the same models image a smaller domain where seismic velocities are slightly lower than average (up to $-0.5 \%$ in the most recent inversion of Rocha et al., 2019, Fig. 16). A strong positive velocity anomaly $(+5 \%)$ onto an average velocity of $4.49 \mathrm{~km} / \mathrm{s}$ is imaged at $100 \mathrm{~km}$ depth beneath the southern part of the SFC in Rayleigh-wave seismic tomography models of South America (Feng et al., 2007; Assumpção et al., 2017). The surface wave model did image the low velocity anomaly beneath the APIP, probably due its lower lateral resolution.

The lateral variations in seismic velocities imaged by these regional tomographic models are consistent with the seismic velocities predicted based on the xenoliths compositions and equilibrium temperatures. A refractory composition of the pristine SFC mantle root is consistent with the on average high Mg\# of olivine and pyroxenes of the coarse-granular peridotites, which overlap with those of xenoliths from other cratonic roots worldwide (Figs. 7 and 8). Such a composition together with a cold geotherm may explain the higher than average seismic velocities and the negative Bouguer anomaly that characterizes the SFC (Assumpção et al., 2017; Rocha et al., 2019). The contrast in seismic velocities beneath the APIP and most of the SFC cannot be explained by Fe-enrichment alone, but it may result from an association of moderate heating of the lithosphere with Fe-enrichment due to reactive melt transport in the lithospheric mantle beneath the APIP. When both effects are considered, the estimated contrast in $\mathrm{P}$-wave anomalies between the cold refractory core of the SFC and the region modified by the APIP magmatism ranges from $1.5 \%$ at $45 \mathrm{~km}$ depth to $3.2 \%$ at $125 \mathrm{~km}$ depth (Fig. 15 and Table 2). For S-waves, it ranges from $2 \%$ at $45 \mathrm{~km}$ depth to $4 \%$ at $125 \mathrm{~km}$ depth (Fig. 15 and Table 2). These estimates are conservative ones, since anelasticity is not considered in the present calculations. In most of the lithospheric mantle, anelastic effects will be negligible, due to the low temperatures and coarse grain sizes (Jackson and Faul, 2010; Takei, 2017). However, at the base of the lithosphere, anelastic effects will result in a larger decrease in seismic velocities for a given temperature increase, especially for long period waves. By consequence, the observed anomalies will require weaker variations in temperature or composition than those modeled here.

Extension of the SFC cratonic mantle beneath the foreland of the Brasilia belt has also been proposed based on seismic refraction data from a line located north of the APIP magmatic province, which showed velocities of $8.23 \mathrm{~km} / \mathrm{s}$ within the shallow lithospheric mantle beneath both the craton and the foreland of the Brasilia belt and of $8.05 \mathrm{~km} / \mathrm{s}$ beneath the Goias magmatic arc (Soares et al., 2006). P-wave velocities observed beneath the eastern Brasilia belt are indeed best fit by the mean P-wave velocities calculated for the average spinel peridotite at $45 \mathrm{~km}$ depth considering a cratonic composition and geotherm (Table 2). A warmer geotherm and more fertile composition are required for reproducing the P-wave velocities observed beneath the Goias magmatic arc.

\section{Conclusion}

The mantle xenoliths analyzed in the present study have sampled the lithospheric mantle beneath the foreland of the Neoproterozoic Brasília belt, within $50 \mathrm{~km}$ from the outcropping limit of the SFC. In addition to a complex tectonic evolution in the Precambrian and early Paleozoic, this region was subjected to extensive mafic-ultrapotassic magmatism in the Cretaceous (APIP). The xenoliths sampled a deep section of the lithospheric mantle (garnet-peridotites and pyroxenites from the Canastra-1 kimberlitic pipe) during the early stages of the APIP magmatism and the upper/middle lithospheric mantle (spinel-peridotites from the Indaiá-1 
and Limeira-1 kimberlitic pipes) during the late stages of the APIP magmatism.

The petrostructural analysis of these mantle xenoliths highlights characteristics similar to observations in cratonic roots worldwide: (1) refractory compositions and coarse-granular microstructures in spinelperidotites, which sampled the upper section of the lithospheric mantle, (2) fine-porphyroclastic, strongly recrystallized microstructures, and more fertile compositions among the garnet-peridotites, which sampled the deep section of the lithospheric mantle, and (3) equilibrium conditions for the garnet-peridotites consistent with a cold geotherm, consistent with a $200 \mathrm{~km}$ thick lithosphere. These data corroborate the continuation of the SFC mantle root beneath the eastern Brasilia belt.

However, the present study also highlights evidence for modification of this cratonic root by reactive melt percolation, with minor associated deformation: (1) development of porphyroclastic microstructures at the expenses of coarse-granular ones in the spinel peridotites, (2) microstructural evidence for secondary crystallization of clinopyroxene and in a lesser extent of orthopyroxene in the spinel peridotites, (3) $\mathrm{Fe}$ enrichment in olivine and pyroxenes, Ti-enrichment in pyroxenes and/ or spinel, and occurrence of modal phlogopite and less frequently amphibole, which are usually associated with coarse-porphyroclastic microstructures in spinel-peridotites, (4) amphibole replacing pyroxenes in coarse-granular or coarse-porphyroclastic pyroxenites, and (5) equilibrium conditions for most spinel-peridotites not consistent with a cratonic geotherm and requiring a warmer geotherm. We interpret these changes as associated with the Cretaceous APIP magmatism, although evidence for older melt-rock interaction events is also preserved in the coarse-granular peridotites. This interpretation is supported by the difference in equilibration conditions between the garnet-peridotites, which were extracted from the mantle at $\sim 120 \mathrm{Ma}$, and the spinel peridotites, which were extracted from the mantle at 80-91 Ma. The former equilibrated on a typical cratonic geotherm, while the latter equilibrated on a warmer geotherm.

The interpretation of local modification of the SFC mantle root by the APIP magmatism is further supported by the fact that the lower seismic velocities observed beneath the APIP $(-0.5 \%$ anomalies) relative to most of the SFC root (up to $+1 \%$ anomalies) in P-wave tomography models (Rocha et al., 2019) may be fully accounted by the moderate heating of the lithosphere and Fe-enrichment due to reactive melt transport in the lithospheric mantle documented in the studied xenoliths. The joint analysis of the mantle xenoliths and seismological data indicates therefore that reactive melt percolation during a major and long-lived magmatic event may effectively change the composition and locally thin a cratonic root.

The present study shows, nevertheless, that this magmatic rejuvenation did not significantly modify the olivine $\mathrm{CPO}$ and, hence, the seismic anisotropy signature of the lithospheric mantle beneath the APIP. Comparison of seismic properties computed based on the xenoliths data with seismological observations implies that fossil flow directions in the cratonic root should be dominantly subhorizontal and that delay times of up to $0.6 \mathrm{~s}$ between the fast and slow split S-waves may be acquired by teleseismic $S$-waves propagating in the cratonic root beneath the area sampled by the xenoliths. Lateral variations in teleseismic S-waves delay times in the southern SFC might therefore record variable obliquity between the lithospheric and asthenospheric flow directions as well as present-day variations in the craton root thickness.

\section{Data availability}

The data used in this article are presented in the figures, tables, and supporting information. The raw EBSD data are available from the corresponding author upon request.

\section{Credit authorship contribution statement}

Priscila Rezende Fernandes: Conceptualization, Investigation, Visualization, Writing - original draft, Writing - review \& editing, Funding acquisition. Andréa Tommasi: Conceptualization, Methodology, Formal Analysis, Validation, Visualization, Data Curation, Writing original draft, Writing - review \& editing, Supervision, Funding acquisition. Alain Vauchez: Formal Analysis, Validation, Visualization, Writing - original draft, Writing - review \& editing. Sergio Pacheco Neves: Supervision, Writing - review \& editing. Felix Nannini: Investigation.

\section{Declaration of Competing Interest}

The authors declare that they have no known competing financial interests or personal relationships that could have appeared to influence the work reported in this paper.

Supplementary data to this article can be found online at https://doi. org/10.1016/j.tecto.2021.229011.

\section{Acknowledgements}

We thank V. Chatzaras and an anonymous reviewer for helpful and very detailed reviews. G. Costa is warmly thanked for providing samples of the Canastra xenoliths. D. Delmas and C. Nevado prepared highquality polished thin sections for EBSD analyses, which were performed with the assistance of F. Barou at the SEM-EBSD INSU national facility at Géosciences Montpellier funded by the CNRS and Université de Montpellier. Electron microprobe analyses at the Université de Montpellier, France were carried out with the assistance of B. Boyer. P.R. F. thanks the Geological Survey of Brazil (SBG/CPRM) and UFPE (Pernambuco Federal University), Brazil for the logistic and financial support for developing her M.Sc project at Géosciences Montpellier. Analysis costs were funded by Geosciences Montpellier.

\section{References}

Abramson, E.H., Brown, M., Slutsky, L.J., Zaug, J., 1997. The elastic constants of San Carlos olivine up to $17 \mathrm{GPa}$. J. Geophys. Res. 102, 12,252-12,263.

Arai, S., 1987. An estimation of the least depleted spinel peridotite on the basis of olivine-spinel mantle array. Neues Jb. Mineral. Monat. 8, 347-354.

Arndt, N.T., Coltice, N., Helmstaedt, H., Gregoire, M., 2009. Origin of Archean subcontinental lithospheric mantle: some petrologicalconstraints. Lithos 109, 61-71.

Assumpção, M., Schimmel, M., Escalante, C., Rocha, M., Barbosa, J.R., Barros, L.V., 2004. Intraplate seismicity in SE Brazil: stress concentration in lithospheric thin spots. Geophys. J. Int. 159, 390-399.

Assumpção, M., Heintz, M., Vauchez, A., Egydio-Silva, M., 2006. Upper mantle anisotropy in SE and Central Brazil from SKS splitting: evidence of asthenospheric flow around a cratonic keel. Earth Planet. Sci. Lett. 250, 224-240.

Assumpção, M., Feng, M., Tassara, A., Julià, J., 2013. Models of crustal thickness for South America from seismic refraction, receiver functions and surface wave tomography. Tectonophysics 609, 82-96.

Assumpção, M., Azevedo, P.A., Rocha, M.P., Bianchi, M.B., 2017. Lithospheric Features of the São Francisco Craton. Tectonic genealogy of a miniature continent. Springer, In São Francisco Craton, Eastern Brazil, pp. 15-25. https://doi.org/10.1007/978-3319-01715-0_2.

Babinski, M., Pedrosa-Soares, A.C., Trindade, R.I.F.D., Martins, M., Noce, C.M., Liu, D., 2012. Neoproterozoic glacial deposits from the Araçuaí orogen, Brazil: Age, provenance and correlations with the São Francisco craton and West Congo belt. Gondwana Res. 21, 451-465.

Bachmann, F., Hielscher, R., Schaeben, H., 2010. Texture Analysis with MTEX - Free and Open Source Software Toolbox. Solid State Phenom. 160, 63-68.

Bachmann, F., Hielscher, R., Schaeben, H., 2011. Grain detection from 2d and 3d EBSD data - Specification of the MTEX algorithm. Ultramicroscopy 111, 1720-1733.

Baptiste, V., Tommasi, A., Demouchy, S., 2012. Deformation and hydration of the lithospheric mantle beneath the Kaapvaal craton, South Africa. Lithos 149, 31-50.

Bascou, J., Tommasi, A., Mainprice, D., 2002. Plastic deformation and development of clinopyroxene lattice preferred orientations in eclogites. J. Struct. Geol. 24, 1357-1368.

Bascou, J., Doucet, L.S., Saumet, S., Ionov, D.A., Ashchepkov, I.V., Golovin, A.V., 2011. Seismic velocities, anisotropy and deformation in Siberian cratonic mantle: EBSD data on xenoliths from the Udachnaya kimberlite. Earth Planet. Sci. Lett. 304, 71-84.

Bastow D., Ian, Julià, J., do Nascimento, A.F, Fuck, R.A, Buckthorp, T., McClellan, J., 2015. Upper mantle anisotropy of the Borborema Province, NE Brazil: Implications 
for 2 intra-plate deformation and sub-cratonic asthenospheric flow. Tectonophysics 657, 81-93. https://doi.org/10.1016/j.tecto.2015.06.024.

Ben Ismail, W., Mainprice, D., 1998. An olivine fabric database: an overview of upper mantle fabrics and seismic anisotropy. Tectonophysics 296, 145-157.

Bernstein, S., Kelemen, P.B., Hanghøj, K., 2007. Consistent olivine Mg\# in cratonic mantle reflects Archean mantle melting to the exhaustion of orthopyroxene. Geology 35, 459-462.

Bizzi, L.A., Schobbenhaus, C., Vidotti, R.M., Gonçalves, J.H., 2003. Geologia, Tectônica e Recursos Minerais do Brasil: texto, mapas e SIG (CPRM).

Boullier, A.M., Nicolas, A., 1975. Classification of textures and fabrics of peridotite xenoliths from South African kimberlites. Phys. Chem. Earth 9, 467-475.

Boyd, F.R., Mertzman, S.A., 1987. Composition and structure of the Kaapvaal lithosphere. In: Mysen, B.O. (Ed.), Magmatic Processes: Physiochemical Principles. Geochemical Society Special Publications, Washington, DC, pp. 13-24.

Boyd, F.R., Nixon, P.H., 1975. Origins of the ultramafic nodules from some kimberlites of northern Lesotho and the Monastery Mine, South Africa. Phys. Chem. Earth 9, 431-454.

Brey, G.P., Köhler, T., Nickel, K.G., 1990. Geothermobarometry in four-phase lherzolites I. Experimental results from 10 to $60 \mathrm{~kb}$. J. Petrol. 31, 1313-1352.

Bunge, H.J., 1982. Texture Analysis in Materials Sciences. Buttleworth, London.

Cabral Neto, I., Nannini, F., Silveira, F.V., Cunha, L.M., 2017. Áreas kimberlíticas e diamantíferas do estado de Minas Gerais (CPRM).

Carlson, R.W., Esperança, S., Svisero, D.P., 1996. Chemical and Os isotopic study of cretaceous potassic rocks from southern Brazil. Contrib. Mineral. Petrol. 125, 393-405.

Carlson, R.W., Araujo, A.L.N., Junqueira-Brod, T.C., Gaspar, J.C., Brod, J.A., Petrinovic, I.A., Hollanda, M.H.B.M., Pimentel, M.M., Sichel, S., 2007. Chemical and isotopic relationships between peridotite xenoliths and mafic-ultrapotassic rocks from Southern Brazil. Chem. Geol. 242, 415-434.

Carvalho, J.B., Leonardos, O.H., 1997. Garnet peridotites from the Três Ranchos 4 kimberlitic pipe, Alto Paranaiba Igneous Province, Brazil: geothermobarometric constraints. Proc. 6th Int. Kimb. Conf. Russ. Geol. Geophys. 38, 168-181.

Chagas de Melo, B., Assumpção, M., "3-Basins" Project Team, 2018. Mantle anisotropy and asthenospheric flow around cratons in southeastern South America. Geophys. J. Int. 215, 494-506.

Chai, M., Brown, J.M., Slutsky, L.J., 1997a. The elastic constants of an aluminous orthopyroxene to 12.5 GPa. J. Geophys. Res. 102, 14779-14786.

Chai, M., Brown, J.M., Slutsky, L.J., 1997b. The elastic constants of a pyrope-grossularalmandine garnet up to 20 GPa. Geophys. Res. Lett. 24, 523-526.

Chang, S.J., Ferreira, A.M., Ritsema, J., van Heijst, H.J., Woodhouse, J.H., 2014. Globa radially anisotropic mantle structure from multiple datasets: a review, current challenges, and outlook. Tectonophysics 617, 1-19.

Collins, M.D., Brown, J.M., 1998. Elasticity of an upper mantle clinopyroxene. Phys. Chem. Miner, 26, 7-13.

Costa, G.V., 2008. Química mineral e geotermobarometria de xenólitos mantélicos do kimberlito Canastra-01. Instituto de Geociências, Universidade de Brasília, Dissertação de mestrado, 137 pp.

Couvy, H., Frost, D.J., Heidelbach, F., Nyilas, K., Ungár, T., Mackwell, S., Cordier, P., 2004. Shear deformation experiments of forsterite at $11 \mathrm{GPa}-1400 \mathrm{C}$ in the multianvil apparatus. Eur. J. Mineral. 16, 877-889.

Dardenne, M.A., 2000. The Brasília fold belt. In: Tectonic Evolution of South America 31st International Geological Congress, Rio de Janeiro, v. 231, p. 263.

Demouchy, S., Tommasi, A., Ballaran, T.B., Cordier, P., 2013. Low strength of Earth's uppermost mantle inferred from tri-axial deformation experiments on dry olivine crystals. Phys. Earth Planet. Inter. 220, 37-49.

Doin, M.P., Fleitout, L., Christensen, U., 1997. Mantle convection and stability of depleted and undepleted continental lithosphere. J. Geophys. Res. 102, 2771-2787.

Durham, W.B., Goetze, C., 1977. Plastic flow of oriented single crystals of olivine. 1. Mechanical data. J. Geophys. Res. 82, 5737-5753. https://doi.org/10.1029/ JB082i036p05737.

Durrheim, R.J., Mooney, W.D., 1991. Archean and Proterozoic crustal evolution: evidence from crustal seismology. Geology 19, 606-609.

Feng, M., Van der Lee, S., Assumpção, M., 2007. Upper mantle structure of South America from joint inversion of waveforms and fundamental mode group velocities of Rayleigh waves. J. Geophys. Res. 112, B04312 https://doi.org/10.1029/ 2006JB004449.

Figueiredo, F.T., De Almeida, R.P., Tohver, E., Babinski, M., Liu, D., Fanning, C.M., 2009 Neoproterozoic glacial dynamics revealed by provenance of diamictites of the Bebedouro Formation, São Francisco Craton, Central Eastern Brazil. Terra Nova 21, 375-385.

Fouch, M.J., Fischer, K.M., Parmentier, E.M., Wysession, M.E., Clarke, T.J., 2000. Shear wave splitting, continental keels, and patterns of mantle flow. J. Geophys. Res. 105, 6255-6275.

French, S.W., Romanowicz, B.A., 2014. Whole-mantle radially anisotropic shear velocity structure from spectral-element waveform tomography. Geophys. J. Int. 199, 1303-1327.

Frets, E., Tommasi, A., Garrido, C.J., Padrón-Navarta, J.A., Amri, I., Targuisti, K., 2012 Deformation processes and rheology of pyroxenites under lithospheric mantle conditions. J. Struct. Geol. 39, 138-157.

Gibson, S.A., Thompson, R.N., Leonardos, O.H., Dickin, A.P., Mitchell, J., 1995. The Late Cretaceous impact of the Trindade mantle plume: evidence from large-volume, mafic, potassic magmatism in SE Brazil. J. Petrol. 36, 189-229.

Goetze, C., 1975. Sheared lherzolites: from the point of view of rock mechanics. Geology 3, 172-173.

Green, H.W., Gueguen, Y., 1974. Origin of kimberlite pipes by diapiric upwelling in upper mantle. Nature 249, 617-620.
Green, H.W., Radcliffe, S.V., 1972. Dislocation mechanisms in olivine and flow in the upper mantle. Earth Planet. Sci. Lett. 15, 239-247.

Griffin, W.L., O'Reilly, S.Y., Ryan, C.G., Gaul, O., Ionov, D., 1998. Secular variation in the composition of subcontinental lithospheric mantle. In: Braun, J., Dooley, J.C., Goleby, B.R., van der Hilst, R.D., Klootwijk, C.T. (Eds.), Structure and Evolution of the Australian Continent, Geodynamics, 26. American Geopyhysical Union, Washington, DC, pp. 1-26.

Griffin, W.L., Ryan, C.G., Kaminsky, F.V., O’Reilly, S.Y., Natapov, L.M., Win, T.T., Kinny, P.D., Ilupin, I.P., 1999. The Siberian Lithosphere Traverse: mantle terranes and the assembly of the Siberian Craton. Tectonophysics 310, 1-35.

Griffin, W.L., O’Reilly, S.Y., Abe, N., Aulbach, S., Davies, R.M., Pearson, N.J., Doyle, B.J., Kivi, K., 2003. The origin and evolution of Archean lithospheric mantle. Precambrian Res. 127, 19-41.

Guarino, V., Wu, F.Y., Lustrino, M., Melluso, L., Brotzu, P., De Barros Gomes, C., Ruberti, E., Tassinari, C.C.G., Svisero, D.P., 2013. U-Pb ages, Sr-Nd-isotope geochemistry, and petrogenesis of kimberlites, kamafugites and phlogopite-picrites of the Alto Paranaíba Igneous Province, Brazil. Chem. Geol. 353, 65-82.

Harte, B., 1977. Rock nomenclature with particular relation to deformation and recrystallisation textures in olivine-bearing xenoliths. J. Geol. 85, 279-288.

Heintz, M., Vauchez, A., Assumpção, M., Barruol, G., Egydio-Silva, M., 2003. Shear wave splitting in SE Brazil: an effect of active or frozen upper mantle flow, or both. Earth Planet. Sci. Lett. 211, 79-95.

Hielscher, R., Schaeben, H., 2008. A novel pole figure inversion method: specification of the MTEX algorithm. J. Appl. Crystallogr. 41, 1024-1037.

Isaak, D.G., Anderson, O.L., Goto, T., Suzuki, I., 1989. Elasticity of single-crystal forsterite measured to 1700 K. J. Geophys. Res. 94, 5895-5906.

Jackson, I., Faul, U.H., 2010. Grain size-sensitive viscoelastic relaxation in olivine: Towards a robust laboratory-based model for seismological application. Phys. Earth Planet. Inter. 183, 151-163.

James, D.E., Assumpção, M., 1996. Tectonic implications of S-wave anisotropy beneath SE Brazil. Geophys. J. Int. 126, 1-10.

King, S.D., 2005. Archean cratons and mantle dynamics. Earth Planet. Sci. Lett. 234, $1-14$.

Klemme, S., 2004. The influence of $\mathrm{Cr}$ on the garnet-spinel transition in the Earth's mantle: experiments in the system $\mathrm{MgO}-\mathrm{Cr} 2 \mathrm{O} 3-\mathrm{SiO} 2$ and thermodynamic modelling. Lithos 77, 639-646.

Kopylova, M.G., Caro, G., 2004. Mantle xenoliths from the southeastern Slave craton: evidence for chemical zonation in a thick, cold lithosphere. J. Petrol. 45, 1045-1067.

Lenardic, A., Moresi, L.N., Mühlhaus, H., 2003. Longevity and stability of cratonic lithosphere: insights from numerical simulations of coupled mantle convection and continental tectonics. J. Geophys. Res. 108, 2303. https://doi.org/10.1029/ 2002JB001859.

Lissenberg, C.J., Dick, H.J., 2008. Melt-rock reaction in the lower oceanic crust and its implications for the genesis of mid-ocean ridge basalt. Earth Planet. Sci. Lett. 271, 311-325.

Liu, S., Tommasi, A., Vauchez, A., Mazzucchelli, M., 2019. Deformation, annealing, meltrock interaction, and seismic properties of an old domain of the equatorial Atlantic lithospheric mantle. Tectonics 38, 1164-1188. https://doi.org/10.1029/ 2018 TC005373.

Mainprice, D., Tommasi, A., Couvy, H., Cordier, P., Fros, D.J., 2005. Pressure sensitivity of olivine slip systems and seismic anisotropy of Earth's upper mantle. Nature 433, 731-733.

Mainprice, D., Hielscher, R., Schaeben, H., 2011. Calculating anisotropic physical properties from texture data using the MTEX open-source package. Geol. Soc. London Spec. Pub. 360, 175-192. https://doi.org/10.1144/SP360.10.

Mainprice, D., Bachmann, F., Hielscher, R., Schaeben, H., 2014. Descriptive tools for the analysis of texture projects with large datasets using MTEX: strength, symmetry and components. Geol. Soc., London. Spec. Pub. 409, 251-271. https://doi.org/10.1144/ SP409.8.

Melo, B.C., Assumpção, M., 2018. Mantle anisotropy and asthenospheric flow around cratons in southeastern South America. Geophys. J. Int. 215, 494-506.

Nannini, F., 2016. Geologia e petrologia de xenólitos mantélicos da Província Ignea do Alto Paranaíba, Minas Gerais. Universidade de São Paulo, Tese de Doutorado. Instituto de Geociências.

Nickel, K.G., Green, D.H., 1985. Empirical geothermobarometry for garnet peridotites and implications for the nature of the lithosphere, kimberlites and diamonds. Earth Planet. Sci. Lett. 73, 158-170.

Nimis, P., Grütter, H., 2010. Internally consistent geothermometers for garnet peridotites and pyroxenites. Contrib. Mineral. Petrol. 159, 411-427.

Paula-Santos, G.M., Babinski, M., Kuchenbecker, M., Caetano-Filho, S., Trindade, R.I., Pedrosa-Soares, A.C., 2015. New evidence of an Ediacaran age for the Bambuí Group in southern São Francisco craton (eastern Brazil) from zircon U-Pb data and isotope chemostratigraphy. Gondwana Res. 28, 702-720.

Pearson, D.G., Canil, D., Shirey, S.B., 2003. Mantle samples included in volcanic rocks: xenoliths and diamonds. Treatise on Geochem. 2, 171-275. https://doi.org/ 10.1016/B0-08-043751-6/02005-3.

Pereira, R.S., Fuck, R.A., 2005. Archean nucleii and the distribution of kimberlite and related rocks in the São Francisco craton, Brazil. Revista Brasileira de Geociências v. 35 (4), 93-104.

Pimentel, M.M., Jost, H., Fuck, R.A., 2004. O embasamento da Faixa Brasília e o arco magmático de Goiás. In: Mantesso Neto, V., Bartorelli, A., Carneiro, C.D.R., BritoNeves, B.B. (Eds.), Geologia do continente Sul-americano: evolução da obra de Fernando Flávio Marques de Almeida, pp. 355-358.

Prado, E.M.G., Soares, J.E.P., Fuck, R.A., 2012. Anisotropia do manto litosferico por repolarização de ondas SKS: implicações na evolução tectônica do Brasil central, in V Simposio Brasileiro de Geofisica (SBGf). 
Raleigh, C.B., Paterson, M.S., 1965. Experimental deformation of serpentinite and its tectonic implications. J. Geophys. Res. 70, 3965-3985.

Read, G., Grutter, H., Winter, S., Luckman, N., Gaunt, F., Thomsen, F., 2004. Stratigraphic relations, kimberlite emplacement and lithospheric thermal evolution, Quiricó basin, Minas Gerais state, Brazil. Lithos 77, 803-818.

Rocha, M.P., Schimmel, M., Assumpção, M., 2011. Upper-mantle seismic structure beneath SE and Central Brazil from P- and S-wave regional traveltime tomography. Geophys. J. Int. 184, 268-286.

Rocha, M.P., Azevedo, P.A., Assumpção, M., Pedrosa-Soares, A.C., Fuck, R., Von Huelsen, M.G, 2019. Delimiting the Neoproterozoic São Francisco Paleocontinental Block with P-wave traveltime tomography. Geophysical Journal International 219 (1), 633-644. https://doi.org/10.1093/gji/ggz323.

Ross, J.V., Nielsen, K.C., 1978. High-temperature flow of wet polycrystalline enstatite. Tectonophysics 44, 233-261.

Seer, H.J., de Moraes, L.C., 2013. Magmatismo granítico Neoproterozoico de ambientes intraplaca, arco e colisão no Grupo Araxá, Faixa Brasília Meridional, Minas Gerais, Brasil. Brazilian J. Geol. 43, 333-354.

Silver, P.G., Savage, M.K., 1994. The interpretation of shear-wave splitting parameters in the presence of two anisotropic layers. Geophys. J. Int. 119, 949-963.

Skemer, P., Karato, S.I., 2008. Sheared lherzolite xenoliths revisited. J. Geophys. Res. 113, B07205 https://doi.org/10.1029/2007JB005286.

Soares, J.E., Berrocal, J., Fuck, R.A., Mooney, W.D., Ventura, D.B.R., 2006. Seismic characteristics of Central Brazil crust and upper mantle: a deep seismic refraction study. J. Geophys. Res. 111, B12302 https://doi.org/10.1029/2005JB00376.

Takei, Y., 2017. Effects of partial melting on seismic velocity and attenuation: a new insight from experiments. Annu. Rev. Earth Planet. Sci. 45, 447-470.
Tommasi, A., Ishikawa, A., 2014. Microstructures, composition, and seismic properties of the Ontong Java Plateau mantle root. Geochem. Geophys. Geosyst. 15, 4547-4569.

Tommasi, A., Vauchez, A., 2015. Heterogeneity and anisotropy in the lithospheric mantle. Tectonophysics 661, 11-37.

Tommasi, A., Tikoff, B., Vauchez, A., 1999. Upper mantle tectonics: three-dimensional deformation, olivine crystallographic fabrics and seismic properties. Earth Planet. Sci. Lett. 168, 173-186.

Tommasi, A., Mainprice, D., Canova, G., Chastel, Y., 2000. Viscoplastic self-consistent and equilibrium-based modeling of olivine lattice preferred orientations: Implications for the upper mantle seismic anisotropy. J. Geophys. Res. 105, 7893-7908.

Ulhein, A., Fonseca, M.A., Seer, H.J., Dardenne, M.A., 2013. Tectônica da faixa de dobramentos Brasília - setores setentrional e meridional. Geognomos 20, 1-14.

Valeriano, C.D.M., Pimentel, M.M., Heilbron, M., Almeida, J.C.H., Trouw, R.A.J., 2008. Tectonic evolution of the Brasília Belt, Central Brazil, and early assembly of Gondwana. Geol. Soc. Lond., Spec. Publ. 294, 197-210.

Van der Wal, D., Chopra, P., Drury, M., Gerald, J.F., 1993. Relationships between dynamically recrystallized grain size and deformation conditions in experimentally deformed olivine rocks. Geophys. Res. Lett. 20, 1479-1482.

Vauchez, A., Dineur, F., Rudnick, R., 2005. Microstructure, texture and seismic anisotropy of the lithospheric mantle above a mantle plume: insights from the Labait volcano xenoliths (Tanzania). Earth Planet. Sci. Lett. 232, 295-314.

Ziberna, L., Klemme, S., Nimis, P., 2013. Garnet and spinel in fertile and depleted mantle: insights from thermodynamic modelling. Contrib. Mineral. Petrol. 166, 411-421. 